\title{
Percursos e desafios da mediação no Mosteiro de São Martinho de Tibães
}

\author{
Joaquim Fernandes Loureiro \\ Direção Regional de Cultura do Norte / Mosteiro de São Martinho de Tibães \\ jloureiro@culturanorte.gov.pt / loureiro.jf@gmail.com
}

\section{Resumo}

O Mosteiro de São Martinho de Tibães, outrora Casa-mãe da Congregação de S. Bento dos Reinos de Portugal, é hoje propriedade do Estado português. Nele coabitam três instituições que exercem as funções cultural, cultual e de acolhimento, fazendo com que todo o conjunto monástico seja uma verdadeira plataforma de encontro de pessoas, culturas, vontades e múltiplas sensibilidades. Neste contexto tão específico, a mediação assume um papel relevante, não apenas como estratégia de prevenção de conflitos, mas como processo de transformação das relações interinstitucionais, pessoais e sociais, capitalizando as diferenças e os diferendos em oportunidades de mudança e de aprendizagem. Pretendemos, assim, refletir e ajudar a clarificar o conceito de mediação, procurando perceber qual a sua importância no campo da Educação Patrimonial. Partindo para o estudo específico de um contexto real de trabalho, este capítulo vai mais além ao investigar sobre: a presença da mediação nos discursos e nas práticas do Mosteiro de São Martinho de Tibães (e em que momentos); os tipos de mediação que estiveram (e ainda estão) presentes na sua vida quotidiana; a forma como a mediação (foi ou ainda é) importante para a concretização dos seus objetivos; e os desafios que enfrentou (ou terá ainda que enfrentar). Reflete também sobre o papel desempenhado pelos mediadores na aproximação entre o público e o bem patrimonial que se pretende dar a conhecer, apresentando um conjunto de desafios que se lhes colocam, definindo ainda aquele que deverá ser o seu perfil de atuação para alcançar os objetivos que lhe foram institucionalmente propostos.

Palavras-chave: Mosteiro de Tibães; Beneditinos; mediação; património; educação.

\section{Courses and Challenges of Mediation in the Monastery of São Martinho de Tibães}

\begin{abstract}
The Monastery of São Martinho de Tibães, once the mother house of the Congregation of S. Bento of the kingdoms of Portugal, is now owned by the Portuguese State. In it, three institutions coexist that perform the cultural, cultural and reception functions, making the whole monastic ensemble a true platform for meeting people, cultures, desires and multiple sensibilities. In this very specific context, mediation assumes an important role, not only as a conflict prevention strategy, but as a process for transforming relations between institutions, personal and social relationships, capitalizing the differences in opportunities for change and learning. We intend to
\end{abstract}


reflect and help clarify the concept of mediation, trying to understand its importance in the field of Heritage Education. Starting with the specific study of a real work context, this chapter goes further by investigating: the presence of mediation in the discourses and practices of the Monastery of São Martinho de Tibães (and at what times); the types of mediation that were (and still are) present in your daily life; how mediation (was or still is) important for the achievement of its objectives; and the challenges you faced (or will face). It also reflects on the role played by mediators, in bringing together the public and the patrimonial asset that is intended to be made known, presenting a set of challenges that arise, also defining what should be their performance profile to achieve the objectives institutionally proposed.

Keywords: Monastery of Tibães; Benedictines; mediation; heritage; education.

\section{Introdução}

O Departamento de Ciências e Técnicas do Património (DCTP) e o seu programa doutoral em Estudos do Património organizaram no dia 08 de novembro de 2019, na Faculdade de Letras da Universidade do Porto, o II Seminário de Estudos do Património. Sob o título Interseções: Rumos e Visões do Património Cultural, foram apresentados diversos estudos e projetos de investigação que, para além de mostrarem a importância da produção de conhecimento em áreas e disciplinas relacionadas com o Património Cultural, assumiram-se, acima de tudo, como importantes meios de identificação, registo, estudo e divulgação patrimonial. A par da vertente teórica, o programa do Seminário contou ainda com uma parte mais orientada para a prática, promovendo a apresentação de outros projetos e ações onde a gestão, salvaguarda, proteção, valorização, comunicação e educação patrimonial estiveram em destaque.

Nesse sentido, a Comissão Organizadora endereçou um convite ao autor para que este desse uma palestra sobre a Mediação Educacional e a sua importância para a salvaguarda do património, tendo em conta a sua atividade de Técnico do Serviço de Educação, que desenvolve no Mosteiro de São Martinho de Tibães (MSMT) há mais de duas décadas. Assim, na tentativa de darmos a conhecer da melhor forma Os percursos e os desafios da mediação no Mosteiro de São Martinho de Tibães, dividimos o nosso trabalho em nove pontos específicos. Os cinco primeiros ajudam-nos a conhecer o Mosteiro, desde a sua fundação até aos nossos dias. Neles encontramos alguns aspetos que serviram de base aos restantes quatro pontos, estes mais voltados para: a apresentação da estratégia educativa e cultural; as ações desenvolvidas ao longo do 
Loureiro, Joaquim Fernandes (2020). Percursos e desafios da mediação no Mosteiro de São Martinho de Tibães. In Alice Duarte (ed.), Seminários DEP/FLUP vol. 1. Porto: Universidade do Porto, Faculdade de Letras/DCTP, p. 62-97. https://doi.org/10.21747/9789898969682/seminariosv1a4

tempo; o estudo da mediação e dos seus atores no contexto específico do MSMT; e os resultados obtidos. Pretendemos assim partilhar experiências, incentivar o debate, promover a reflexão e contribuir para a criação de um conhecimento mais alargado no campo da Mediação e da Educação Patrimonial.

\section{Enquadramento geográfico do Mosteiro de São Martinho de} Tibães

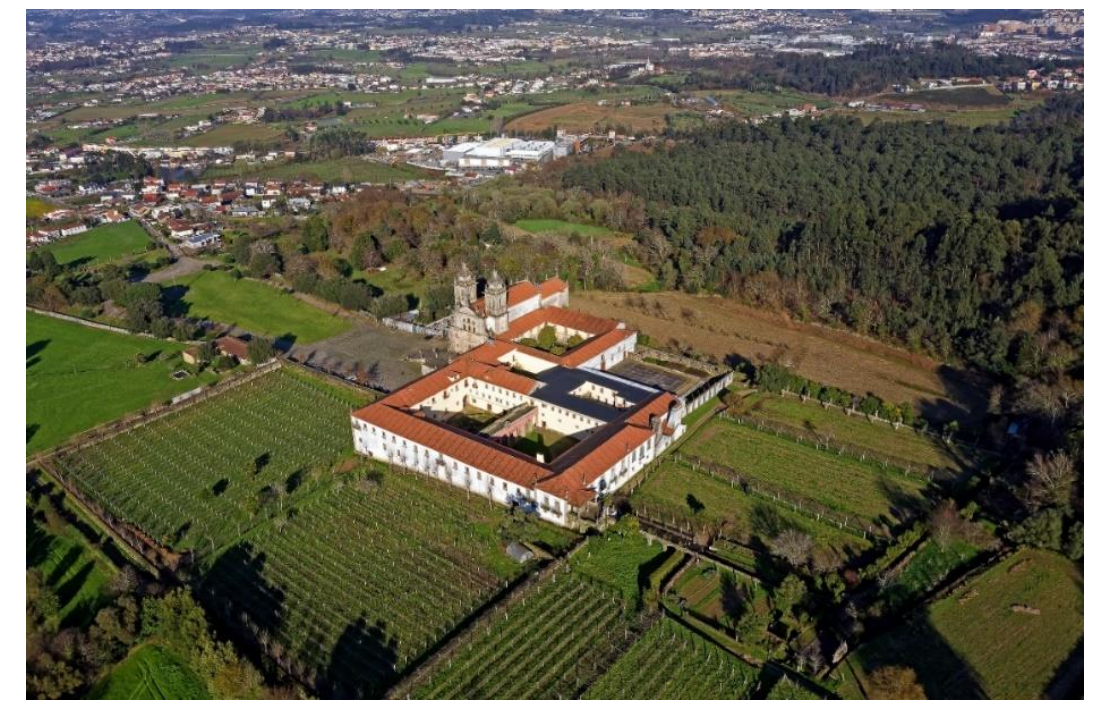

Figura 1 - Vista aérea do Mosteiro de São Martinho de Tibães.

(2020, Arquivo do MSMT®, fotografia de Carlos Sousa Pereira)

No norte de Portugal, em pleno coração do Minho, no concelho de Braga, na freguesia de Mire de Tibães, aproximadamente a $6 \mathrm{~km}$ da cidade de Braga, encontramos o Mosteiro de São Martinho de Tibães. Construído a meia encosta, na vertente norte do monte de São Gens, o Mosteiro possui ao seu redor uma vasta área florestal onde, para além do carvalhal, o pinhal e o eucaliptal têm ganho terreno nas últimas décadas.

Outrora proprietário de um vasto conjunto de terras, que se alongavam desde o seu terreiro até às margens do rio Cávado, hoje o Mosteiro mantém ainda a sua posição sobranceira e de destaque na paisagem da região, vendo progressivamente desaparecer o verde dos campos e montes para dar lugar ao colorido desregrado de um grande conjunto de construções destinadas à habitação, à indústria, ao comércio e aos serviços. A paisagem rural que marcou Mire de Tibães ao longo de séculos está agora reduzida a pequenas parcelas de terreno cultivadas por algumas famílias que ainda vão arranjando 
tempo para manter a tradição. Na verdade, os setores secundário e terciário foram ganhando espaço e trazendo consigo uma azáfama que foi progressivamente transformando a paisagem e a pacatez de uma aldeia, numa zona com mais movimento e, consequentemente, com mais poluição.

Hoje, a par do importante centro cultural, cultual, ambiental e de acolhimento que é o Mosteiro, a freguesia de Mire de Tibães possui outros serviços, entre os quais o Centro de Saúde, o Jardim-de-Infância, a Escola do Primeiro Ciclo e o Centro Social. Os dados recolhidos no Censos $2011^{1}$ demonstraram o progressivo crescimento da freguesia e revelaram que nessa data Mire de Tibães possuía 2437 habitantes, 795 famílias, 909 alojamentos e 823 edifícios. Podemos afirmar que, aos poucos, a freguesia está a ficar quase dentro do perímetro urbano e a tornar-se como que um dormitório da cidade de Braga.

\section{A história do mosteiro: da fundação até 1986}

Segundo Frei Leão de São Tomás (São Tomás, 1974), importante cronista beneditino, a fundação do primitivo mosteiro remonta ao ano de 562, no tempo do rei suevo Teodomiro. Contudo, o desconhecimento de documentos referentes ao Mosteiro anteriores ao século $\mathrm{XI}$, bem como a inexistência de materiais líticos e cerâmicos do período suevo/visigótico no espólio recolhido durante as escavações arqueológicas, realizadas entre 1992 e 2000 (Fontes, 2005), permitem colocar em dúvida aquela data de fundação. Segundo Aida Mata (2011: 92), a fundação do Mosteiro, no local onde hoje se encontra, terá sido em finais do século XI, por ação da família de D. Paio Guterres da Silva. Em 1110 o Mosteiro recebe a Carta de Couto, pelo Conde D. Henrique e sua mulher D. Teresa, juntando à posse das terras, os poderes judicial e municipal (Ramos, 2017). O Couto de Tibães era composto por uma vasta área de terrenos, na margem esquerda do rio Cávado, perfeitamente delimitada pelo próprio rio e por um conjunto de marcos pétreos, identificados e estudados por José Carlos Peixoto (Peixoto, 2014) e classificados pela Assembleia Municipal de Braga, no dia 12 de fevereiro de 2016, como Património

\footnotetext{
${ }^{1}$ Dados disponíveis na página: http://www.jf-miretibaes.pt/index.php/freguesia/mire-de-tibaes/um-poucosobre-a-freguesia, acedida em 02-11-2019.
} 
Loureiro, Joaquim Fernandes (2020). Percursos e desafios da mediação no Mosteiro de São Martinho de Tibães. In Alice Duarte (ed.), Seminários DEP/FLUP vol. 1. Porto: Universidade do Porto, Faculdade de Letras/DCTP, p. 62-97. https://doi.org/10.21747/9789898969682/seminariosv1a4

de Interesse Municipal². O alargamento territorial do Couto de Tibães acontece ao longo dos séculos seguintes (Peixoto, 2017), tornando o Mosteiro numa das mais influentes casas religiosas existentes acima do Douro.

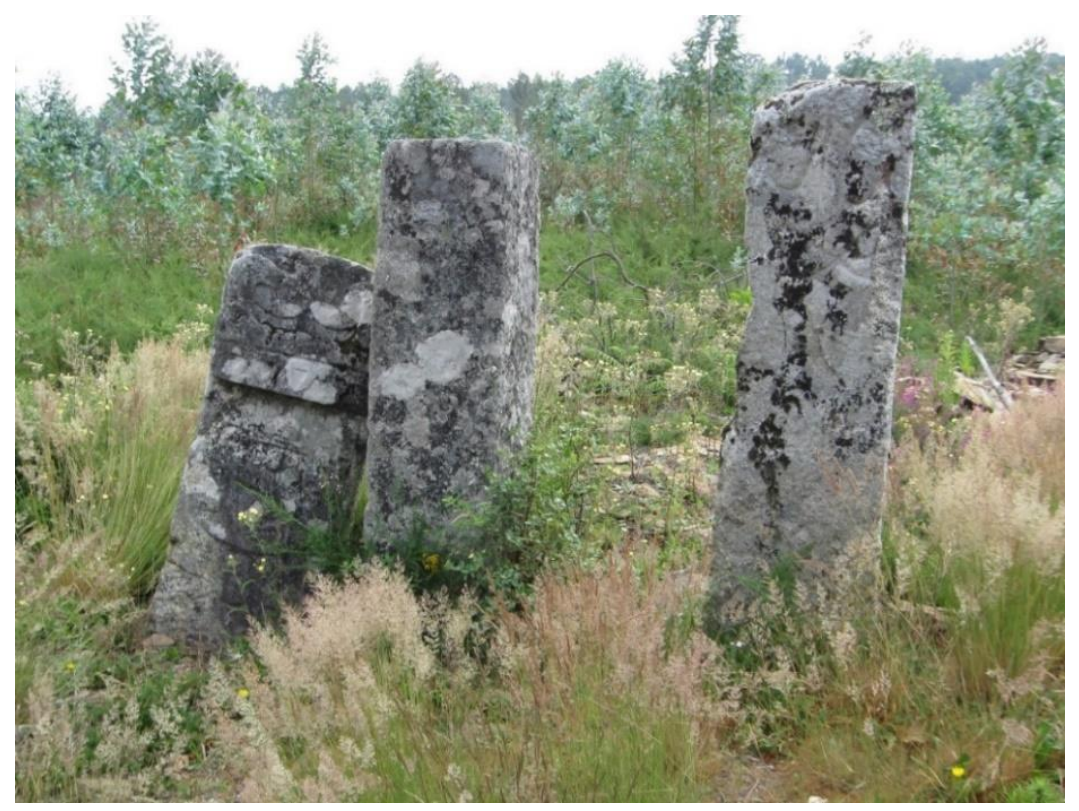

Figura 2 - Marcos de delimitação do Couto e freguesia de Mire de Tibães, na zona de Abelheiró.

(2013, Arquivo do MSMT@, fotografia de Joaquim Loureiro)

A riqueza gerada pela posse das terras e o inerente crescimento económico rapidamente trouxeram também consigo a cobiça e a má gestão, o que, associado a um vasto conjunto de fatores de âmbito nacional, levaram o Mosteiro a passar por várias crises sucessivas, entre finais do século XIV e meados do século XVI (Marques, 1981). A degradação económica, social e moral vivida no interior dos mosteiros é o mote para que, após o Concílio de Trento, se desse início a uma profunda reforma no modo de viver em comunidade. Tais alterações não se ficaram unicamente pelo ponto de vista religioso, mas tiveram implicações de fundo na sociedade e na paisagem, pela forma como, ao serviço da Igreja, se foram desenvolvendo a arte, a arquitetura, a música e a ciência. O espírito reformista chega a Portugal e aos beneditinos. Assim, indo ao encontro das disposições saídas do Concílio de Trento, o MSMT é escolhido em 1567 para Casa-Mãe da Congregação Beneditina dos Reinos de Portugal, passando a ser a sede de 22 mosteiros em Portugal e 13 no Brasil (Mata, 2011:99).

\footnotetext{
${ }^{2}$ Ata da Assembleia Municipal de Braga n. ${ }^{\circ} 16$, de 12-02-2016, disponível em file:///D:/Tranfer\%C3\%AAncias/ATA_N__16-2016_de_12_fevereiro_de_2016_XI_mandato_.pdf, acedida em 06-11-2019..
} 
Loureiro, Joaquim Fernandes (2020). Percursos e desafios da mediação no Mosteiro de São Martinho de Tibães. In Alice Duarte (ed.), Seminários DEP/FLUP vol. 1. Porto: Universidade do Porto, Faculdade de Letras/DCTP, p. 62-97. https://doi.org/10.21747/9789898969682/seminariosv1a4

$\mathrm{Na}$ primeira metade do século XVII deu-se início à grande campanha de reedificação e ampliação do Mosteiro, da qual resultou o conjunto hoje existente. 0 início das obras segue a corrente maneirista, mas o barroco e o rococó haveriam de dominar as alterações realizadas nos finais do século XVII e ao longo de todo o século XVIII.

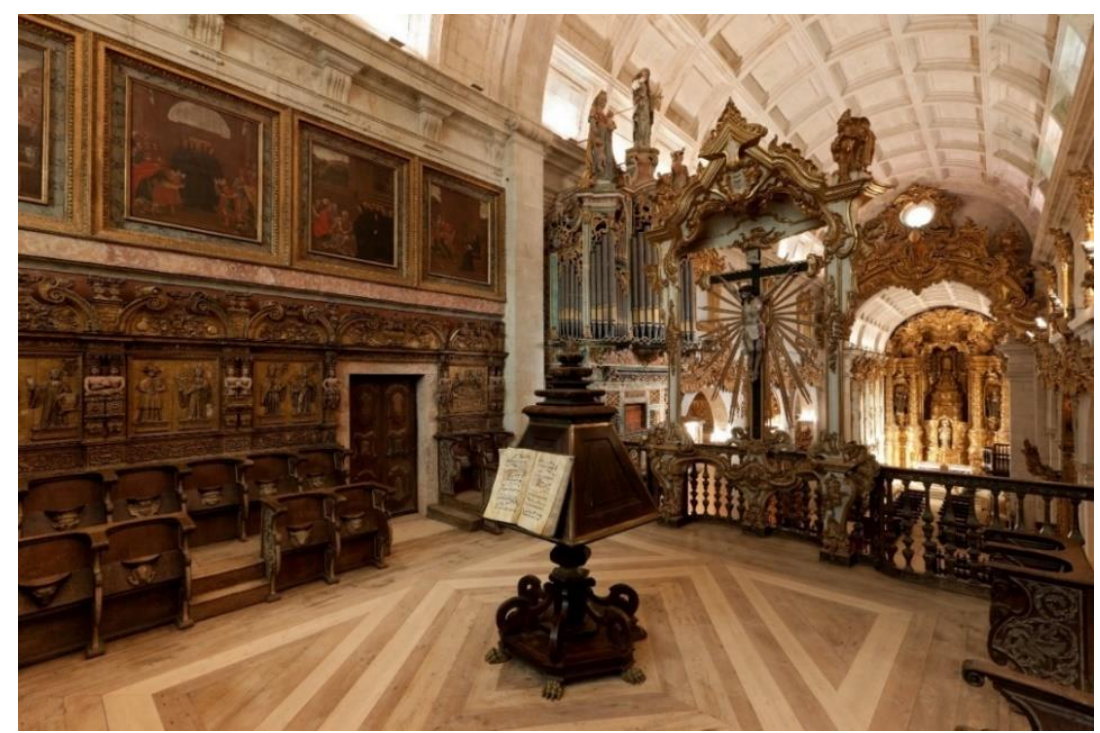

Figura 3 - Vista geral do interior da igreja do Mosteiro de São Martinho de Tibães. (2009, Arquivo do MSMTC, fotografia de Luís Ferreira Alves)

A chegada do século XIX trouxe consigo crises políticas, económicas e sociais, conflitos doutrinais e ideológicos e as invasões francesas. Assistiu-se ao progressivo empobrecimento material e moral da sociedade em geral e das ordens religiosas em particular, culminando, no caso destas últimas, com a sua extinção, no início da década de 30 (Oliveira, 2005). Com a extinção das ordens religiosas, o Mosteiro é encerrado em $1833 / 1834$ e os seus bens inventariados e vendidos. A igreja, a sacristia, o claustro do cemitério, uma parte para residência do pároco e o passal, ficam de imediato em uso paroquial. As restantes áreas da cerca conventual e do edificado monástico são vendidas em hasta pública, passando para mãos particulares, nos anos de 1838 e 1864, respetivamente (Santos, 1987).

No dia 11 de julho de 1894, um grande incêndio destruiu aproximadamente um quarto da área edificada. Claustro do refeitório, refeitório, casa dos fogões, noviciado, coristado, hospício, oficinas, casa das pinturas e dormitórios (nascente e sul) ficaram irremediavelmente destruídos. Até meados do século $\mathrm{XX}$, a utilização privada foi 
Loureiro, Joaquim Fernandes (2020). Percursos e desafios da mediação no Mosteiro de São Martinho de Tibães. In Alice Duarte (ed.), Seminários DEP/FLUP vol. 1. Porto: Universidade do Porto, Faculdade de Letras/DCTP, p. 62-97. https://doi.org/10.21747/9789898969682/seminariosv1a4

mantendo e preservando os espaços. Nas décadas seguintes, principalmente a partir dos anos 70, com a mudança dos proprietários, assiste-se à degradação progressiva de todo o conjunto monástico. Aos poucos, azulejos, pinturas, fontes, livros, pedras e talha começam a ser vendidos, oferecidos e até destruídos.

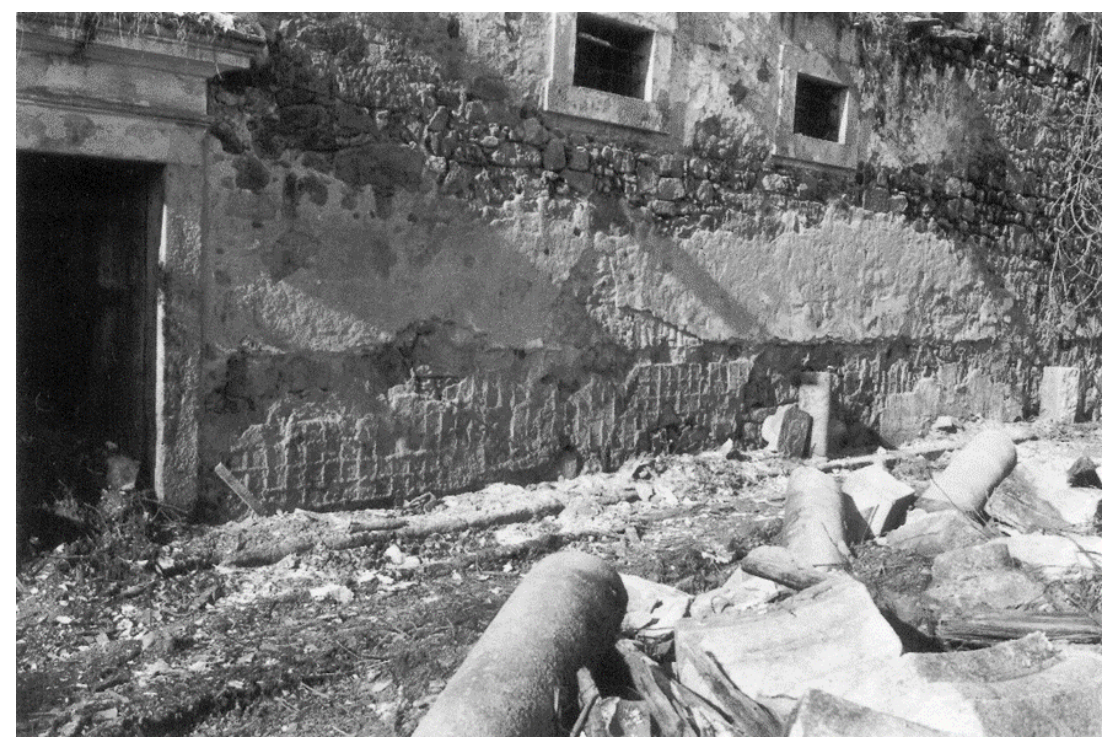

Figura 4 - Desmantelamento do claustro do refeitório do Mosteiro de São Martinho de Tibães. (1983, Arquivo do MSMTC, fotografia de Maria João Vasconcelos)

A cerca também sofreu uma transformação enorme, não apenas pela exploração do volfrâmio que foi feita nas suas terras por altura da Segunda Guerra Mundial, mas também porque os campos deixaram de ser cultivados. Rapidamente, os silvados e as espécies invasoras começaram a ganhar terreno e a ocupar os pomares, o olival e os jardins. Apesar de habitado por privados até 1986 e de ver classificadas as suas construções, o conjunto monástico não deixou de conhecer o abandono, a incúria e a indiferença, ficando vazio e em avançado estado de degradação (Mata \& Costa, 1988).

Perante este cenário de perda iminente e irreparável de todo um conjunto de grande valor patrimonial, a sociedade civil fez grande pressão sobre o Estado português, através de várias entidades ${ }^{3}$, iniciando-se um longo e complexo processo negocial (adiante esquematizado) que culminou com a compra do Mosteiro e da cerca por parte do Estado, em 18 de agosto de 1986. Desta forma foi dado um primeiro passo para a

\footnotetext{
${ }^{3}$ Destacou-se neste campo a ação da ASPA - Associação para a defesa, estudo e divulgação do património cultural e natural de Braga.
} 
Loureiro, Joaquim Fernandes (2020). Percursos e desafios da mediação no Mosteiro de São Martinho de Tibães. In Alice Duarte (ed.), Seminários DEP/FLUP vol. 1. Porto: Universidade do Porto, Faculdade de Letras/DCTP, p. 62-97. https://doi.org/10.21747/9789898969682/seminariosv1a4

salvaguarda e proteção de todo o conjunto monástico, de modo a serem futuramente criadas as bases para o seu estudo, valorização e dinamização educativa e cultural.

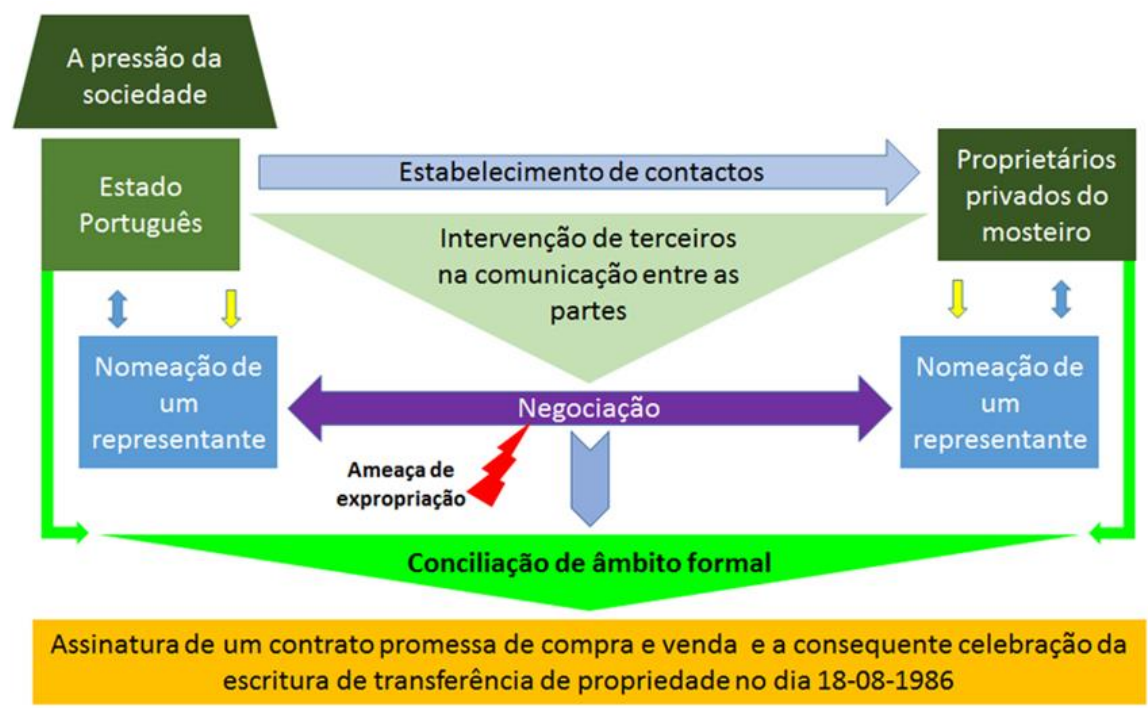

Figura 5 - Esquematização do processo negocial de aquisição do Mosteiro de São Martinho de Tibães. (2014, Arquivo do MSMTC, esquema desenhado por Joaquim Loureiro)

\section{Após a compra pelo Estado}

Celebrada a escritura de transferência de propriedade, o Estado português assumiu a posse administrativa do Mosteiro e determinou que os antigos proprietários tinham que o abandonar até ao dia 31 de dezembro de 1986, sob pena de lhes ser aplicada uma coima por cada dia que passasse para além do prazo estabelecido (Loureiro, 2013:52). No dia 01 de janeiro de 1987, o Estado assumiu a posse material de todo o conjunto monástico. De imediato várias questões se foram colocando. Recuperar para quê? Qual o objetivo da recuperação? Que funções dar aos espaços? 


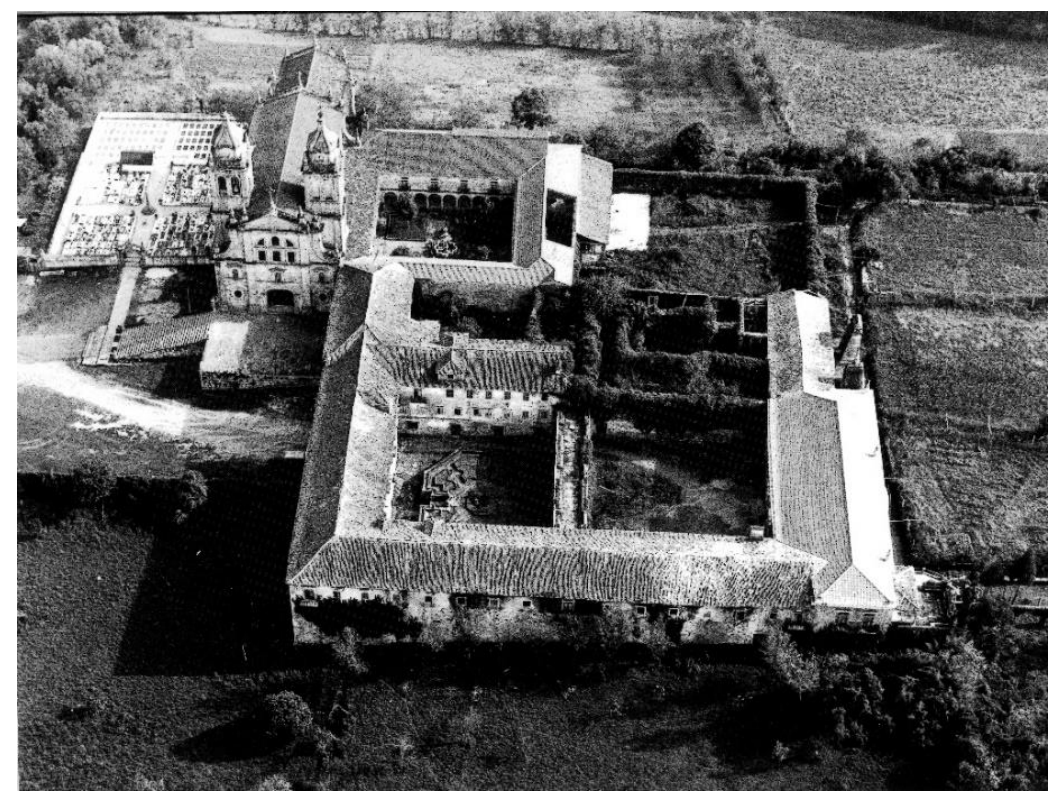

Figura 6 - Vista aérea do Mosteiro de São Martinho de Tibães, logo após a compra pelo Estado Português. (1987, Arquivo do MSMTC, fotografia de Miguel Louro)

Enquanto se refletia sobre o futuro e se estudava o passado, o trabalho de campo foi avançando e, lentamente, os espaços do edifício, outrora escondidos e danificados, foram sendo limpos, colocando a descoberto um património ainda desconhecido. A limpeza foi também feita na cerca, com a ajuda do Exército, de técnicos do Parque Nacional da Peneda-Gerês e com o conhecimento e experiência de trabalhadores rurais, residentes nas imediações do Mosteiro. Abrem-se caminhos, retiram-se entulhos, combatem-se as espécies invasoras, limpam-se as minas, reconduzem-se as águas e refazem-se os muros. Colocam-se telhados provisórios, criam-se passadiços, recuperam-se as portas e janelas principais e instalam-se as redes básicas de eletricidade, água, saneamento e de telecomunicações. Criam-se as condições mínimas de segurança e o Mosteiro reabre ao público, pois é necessário iniciar o trabalho educativo e de relação de proximidade com todos. Começam também a ganhar forma um conjunto de ideias inerentes à ocupação do espaço e definem-se aquelas que viriam a ser as suas principais funções:

- cultural e religiosa - com vista a manter a igreja do Mosteiro como centro de culto religioso e atividade paroquial, sendo para isso necessário criar e recuperar outras estruturas de apoio (residência paroquial, salas de catequese, espaço para arrumos e sanitários); 


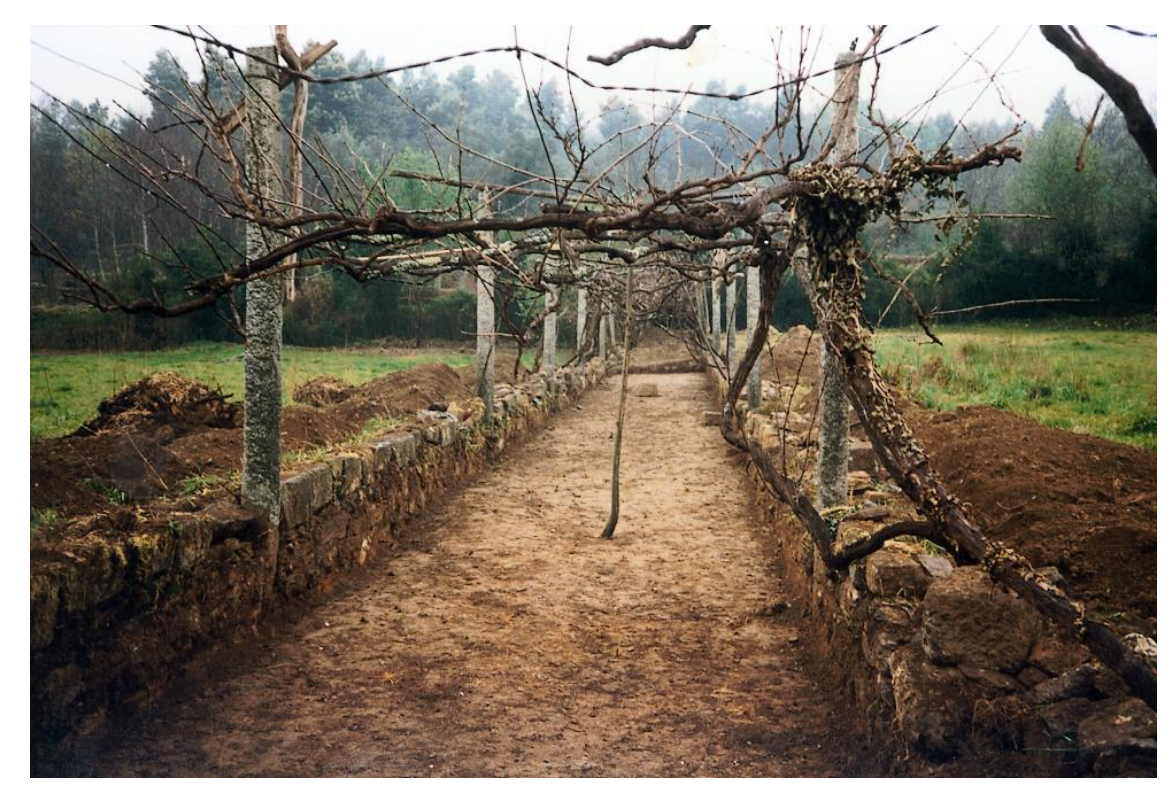

Figura 7 - Recuperação de caminho e ramada, junto aos campos da horta. (1988, Arquivo do MSMTC, fotografia de Maria João Dias Costa)

- cultural - para abrir o monumento-museu, no sentido de promover a preservação do património cultural, o estudo, a produção de conhecimento, a educação, a dinamização cultural, a conservação, o restauro e a recuperação;

- de acolhimento - instalando uma nova comunidade religiosa, responsável pela gestão de uma hospedaria e de um restaurante.

Com a criação institucional do Museu do Mosteiro de São Martinho de Tibães, em 28 de setembro de $1990^{4}$, dá-se o devido suporte legal para o desempenho da sua missão, muito centrada na produção de conhecimento sobre: o MSMT; a região do antigo Couto de Tibães; e a Ordem Beneditina.

Os trabalhos arqueológicos têm início e avançam em várias frentes. Aprofundase o conhecimento histórico e sustenta-se a base de atuação futura das obras de recuperação, restauro e reabilitação. Dá-se formação à equipa de trabalho. Segue-se, em 1992, a criação do Serviço de Educação, responsável pela organização sistemática de ações educativas e de dinamização cultural com o objetivo claro de criar relações de

\footnotetext{
${ }^{4}$ Diário da República, I SÉRIE, N.o 225, Decreto-Lei n.o 307/90, de 28 de setembro.
} 
Loureiro, Joaquim Fernandes (2020). Percursos e desafios da mediação no Mosteiro de São Martinho de Tibães. In Alice Duarte (ed.), Seminários DEP/FLUP vol. 1. Porto: Universidade do Porto, Faculdade de Letras/DCTP, p. 62-97. https://doi.org/10.21747/9789898969682/seminariosv1a4

proximidade com a comunidade local, valorizando o seu conhecimento prático, as suas profissões e os seus usos e costumes.

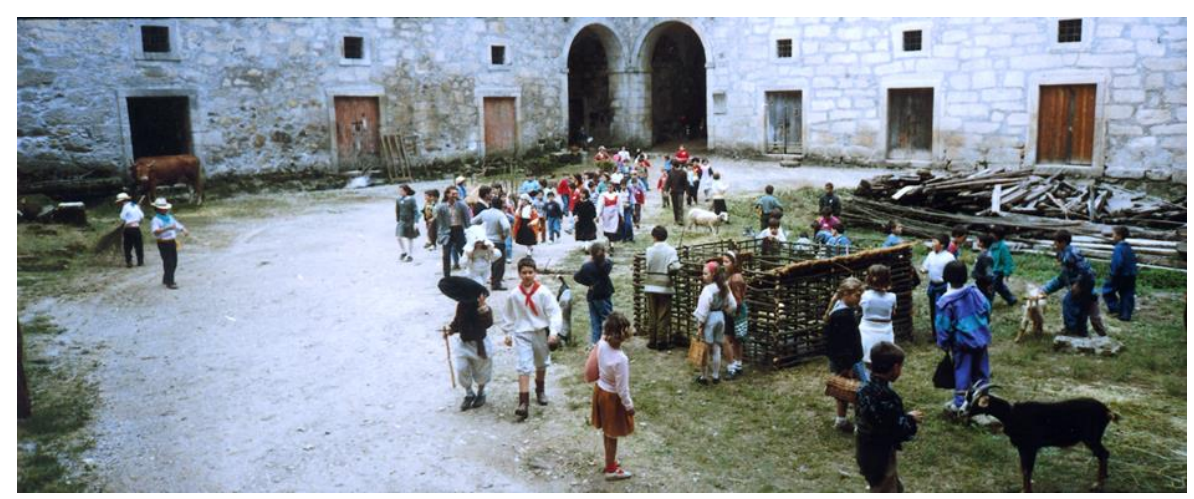

Figura 8 - Representação de algumas cenas do livro Uma viagem no tempo ao Mosteiro de Tibães. (1992, Arquivo do MSMTC, fotografia de Paulo Oliveira)

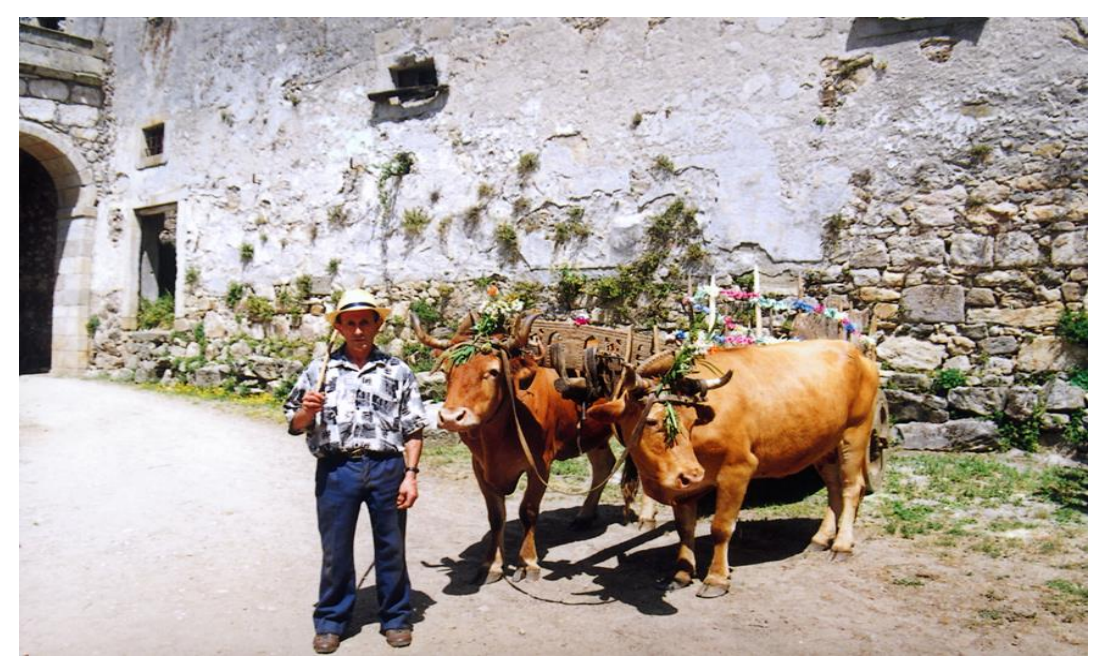

Figura 9 - Carro de bois do Sr. Manuel Joaquim Gomes (Zé Joaquim dos Carvalhos), enfeitado para a inauguração da Exposição Uma memória rural no Couto de Tibães. (1993, Arquivo do MSMTC, fotografia de Paulo Oliveira)

\section{A recuperação dos espaços}

Com a ruína estabilizada e as construções principais consolidadas, pensa-se a seguir na criação de novas infraestruturas, mais modernas, capazes de se adequarem aos objetivos de utilização espacial entretanto assumidos e, ao mesmo tempo, adequadas a dar resposta, com qualidade, a um número crescente de visitantes. Recorrendo ao financiamento dos Quadros Comunitários de Apoio, foi possível criar as redes de abastecimento de água, de recolha e tratamento de esgotos, de incêndio, de eletricidade e de telecomunicações. A par destes trabalhos avançam ainda a 
Loureiro, Joaquim Fernandes (2020). Percursos e desafios da mediação no Mosteiro de São Martinho de Tibães. In Alice Duarte (ed.), Seminários DEP/FLUP vol. 1. Porto: Universidade do Porto, Faculdade de Letras/DCTP, p. 62-97. https://doi.org/10.21747/9789898969682/seminariosv1a4

recuperação, restauro e reabilitação progressiva dos espaços, com vista ao estabelecimento do circuito museológico, à conservação do património móvel e à sua fruição por parte do público. No ano de 1994 dá-se início à construção da nova residência paroquial. Entre 1998 e 2000 procede-se ao restauro, recuperação e reabilitação da ala norte, com a criação da sala de exposições temporárias (antiga sala do recibo), a zona técnica de apoio, a sala polivalente (outrora a cavalariça), os sanitários para os visitantes e a receção. No ano 1999 tem início a recuperação integrada de restauro e recuperação da igreja, terminando em junho de 2000. Segue-se o restauro, recuperação e reabilitação do claustro do cemitério, entre 2000 e 2002 (Pereira et al., 1997:53-56).

As obras voltariam apenas uns anos mais tarde, quando, entre 2006 e 2009, se procedeu à recuperação e reabilitação do noviciado, ala sul e claustro do refeitório, instalando-se no Mosteiro uma hospedaria e um restaurante, ambos geridos por uma comunidade religiosa. Ainda em 2009 construiu-se a loja e reabilitou-se a casa do volfrâmio. As grandes obras finalizaram em 2012 com a pavimentação e reorganização paisagística de todo o terreiro em frente ao mosteiro.
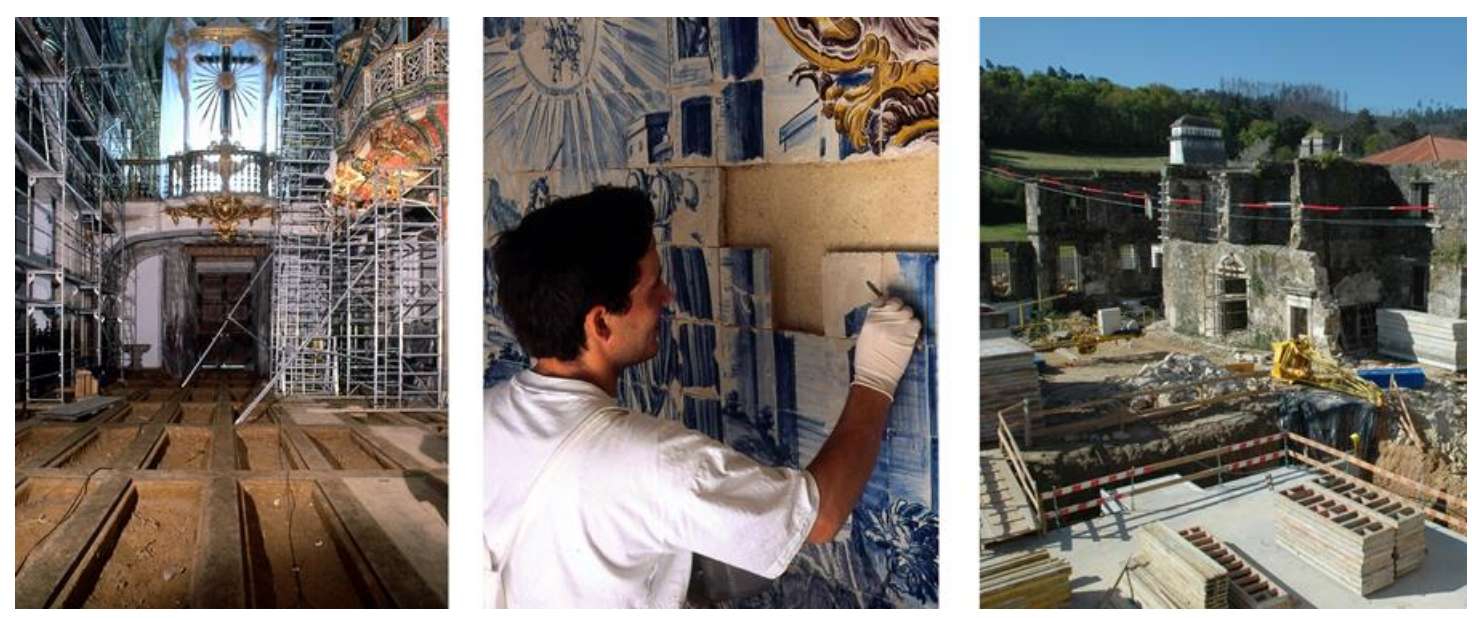

Figura 10 - Restauro e reabilitação do Mosteiro de São Martinho de Tibães, da esquerda para direita: Igreja; Azulejos do claustro do cemitério; Noviciado e claustro do refeitório.

(Arquivo do MSMTC, fotografias de: Luís Ferreira Alves - 1 > 1999 | 2 > 2001 e Jorge Inácio - 3 > 2007) 
Loureiro, Joaquim Fernandes (2020). Percursos e desafios da mediação no Mosteiro de São Martinho de Tibães. In Alice Duarte (ed.), Seminários DEP/FLUP vol. 1. Porto: Universidade do Porto, Faculdade de Letras/DCTP, p. 62-97. https://doi.org/10.21747/9789898969682/seminariosv1a4

\section{O Mosteiro na atualidade}

O conjunto monástico é composto pelo cruzeiro $^{5}$, igreja, alas conventuais e demais construções arquitetónicas da cerca ${ }^{6}$, sendo abrangido por uma área especial de proteção desde 19497, a qual foi alargada em agosto de $1994^{8}$. Apesar de ser propriedade do Estado português, o seu uso é partilhado por três diferentes instituições:

- Direção Regional de Cultura do Norte (DRCN), responsável pela gestão do monumento e pela sua proteção, salvaguarda, recuperação, restauro e reabilitação. A DRCN/MSMT tem ainda a seu cargo o acolhimento do público e a promoção do estudo e da investigação, com vista à dinamização educativa e cultural de todo o conjunto monástico;

- $\quad$ Paróquia de Mire de Tibães, responsável pela vertente cultual e por todas as atividades relacionadas com a vida paroquial;

- Diocese de Braga, que através de uma comunidade religiosa instalada na zona reabilitada do antigo noviciado e coristado, assegura a função de acolhimento e de gestão de uma hospedaria e de um restaurante.

Todas estas instituições, conscientes da importância do património que utilizam, procuram, nas suas mais diversas ações, trazer mais dinamismo ao Mosteiro, realizando as suas atividades de acordo com as regras de proteção e preservação patrimonial.
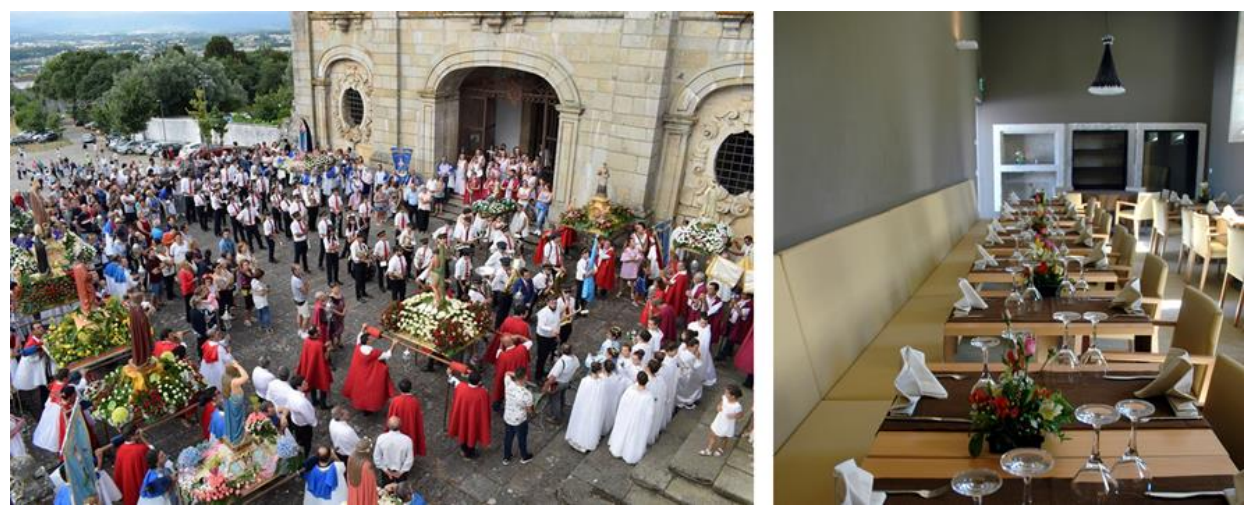

Figura 11 - Uso partilhado do Mosteiro de São Martinho de Tibães, da esquerda para direita: Procissão de São Sebastião; Restaurante; (Arquivo do MSMT@, fotografias de: Arlindo Pinheiro - $1>2018$ e Jorge Inácio - 2 > 2010)

\footnotetext{
${ }^{5}$ Classificado como monumento nacional desde 16 de junho de 1910, de acordo com o Diário do Governo n.o 136/1910, de 23 de junho.

${ }^{6}$ Classificados como imóveis de interesse público pelo decreto n.o 33587, de 27 de março de 1944.

7 Diário da República n. 242, II série, de 18 de outubro de 1949.

8 Portaria n.o $736 / 94$ de 13 de agosto.
} 
Num contexto tão particular como este, em que cada uma das instituiç̧̃es tem as suas relações internas e externas específicas, persegue os seus próprios objetivos, lida com diferentes tipos de público, coabitando no mesmo espaço com múltiplas sensibilidades, poderemos afirmar que estão criadas as condições ideais para o surgimento constante de problemas. Contudo, esta situação é também uma oportunidade para que os diferentes atores que exercem a sua atividade profissional neste contexto possam transformar as dificuldades em oportunidades, desenvolvendo um conjunto de características pessoais e profissionais que procuram ir ao encontro do crescimento mútuo, do consenso e da partilha. Digamos que o MSMT é um palco privilegiado para a entrada em cena da mediação!

\section{As ações educativas e culturais}

Feito o enquadramento histórico e geográfico do MSMT, apresentados os seus principais objetivos de ação, conhecidas algumas das mais marcantes intervenções de conservação, restauro e reabilitação e exposto o seu modo de funcionamento atual, importa agora conhecer a face mais visível do trabalho que tem sido realizado. Debruçámo-nos, em particular, sobre as ações educativas e culturais desenvolvidas pela equipa do MSMT. Estas resultam da produção própria do Serviço de Educação, mas também são a materialização no terreno de um conjunto de parcerias e protocolos estabelecidos com outras entidades e com especialistas nas mais diversas áreas do saber. Não se resumem a uma abordagem redutora do património exclusivamente edificado, mas procuram-no dar a conhecer de uma forma mais holística, explorando também o meio em que este se insere. Com frequência são realizadas atividades que abordam o património imaterial, etnográfico, geológico, ambiental, religioso, hidráulico e musical, ainda presente, de forma bem visível, no conjunto monástico e na região do antigo Couto de Tibães.

Anualmente é elaborado o programa de atividades do Serviço de Educação, o qual é divulgado pelos canais próprios de comunicação do MSMT. Nele estão registadas um conjunto base de ações, preparadas de acordo com os recursos humanos disponíveis, os espaços a visitar, as épocas do ano e os públicos que se pretendem 
Loureiro, Joaquim Fernandes (2020). Percursos e desafios da mediação no Mosteiro de São Martinho de Tibães. In Alice Duarte (ed.), Seminários DEP/FLUP vol. 1. Porto: Universidade do Porto, Faculdade de Letras/DCTP, p. 62-97. https://doi.org/10.21747/9789898969682/seminariosv1a4

alcançar. Na prática é um documento orientador e uma base de trabalho que, a qualquer momento, pode ser ampliada de acordo com outras ofertas que possam surgir e que sejam encaradas como adequadas aos objetivos do MSMT. Apresentamos de seguida as atividades constantes do programa do Serviço de Educação e algumas informações relevantes sobre as mesmas:

a) Visitas preparatórias - Visita específica.

Dirigida aos responsáveis pelos grupos que pretendem visitar o MSMT. A equipa do Serviço de Educação dá a conhecer os espaços, mostra as acessibilidades e, de acordo com os objetivos traçados pelos responsáveis do grupo, a idade dos participantes, o ano de escolaridade e outras necessidades específicas, apresenta-lhes as atividades disponíveis e mais ajustadas ao grupo.

Público-alvo: técnicos de educação e formação, guias turísticos e organizadores de eventos; Horário: a combinar, de segunda a sexta-feira; empo de visita: 2h30; N. máximo de participantes: 50 .

b) São Martinho, o Cavaleiro do Sol! - Espetáculo de marionetas.

São Martinho de Tours, padroeiro do Mosteiro e de Mire de Tibães, serve de tema a um espetáculo de marionetas que, utilizadas como elo de ligação entre o passado e o presente, mostram que a História pode ser divertida!

Público-alvo: 4 aos 10 anos; Data e horário: novembro, quartas e sextas-feiras, às $10 \mathrm{~h} 00$ ou 14h30; Tempo de visita: 1h30; N. áximo de participantes: 50.

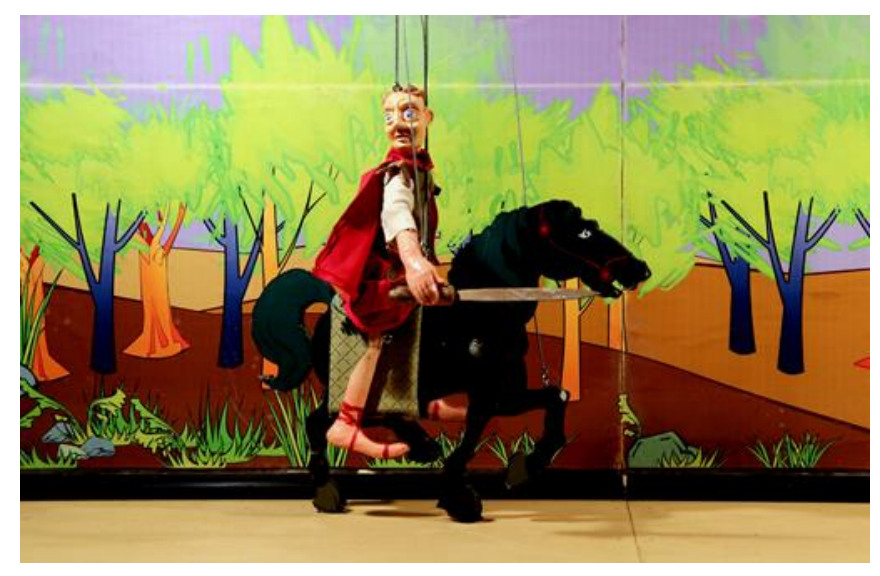

Figura 12 - São Martinho, o Cavaleiro do Sol!, espetáculo de marionetas. (2019, Arquivo do MSMTC), fotografia de Joaquim Loureiro) 
Loureiro, Joaquim Fernandes (2020). Percursos e desafios da mediação no Mosteiro de São Martinho de Tibães. In Alice Duarte (ed.), Seminários DEP/FLUP vol. 1. Porto: Universidade do Porto, Faculdade de Letras/DCTP, p. 62-97. https://doi.org/10.21747/9789898969682/seminariosv1a4

c) Hmmm... Há monges no mosteiro! - Espetáculo de marionetas.

Hugo, um menino muito curioso, inicia uma viagem no tempo com destino ao longínquo século XVIII. Sem que ele saiba, viaja com ele o seu gato, o Branquinho, pondo em risco o seu regresso. No final da peça propõe-se às crianças uma visita ao Mosteiro, à procura dos amigos do Branquinho.

Público-alvo: 4 aos 10 anos; Data e horário: janeiro e fevereiro, quartas e sextasfeiras, às 10 h00 ou 14h30; Tempo de visita: 2 horas; N. máximo participantes: 50.

d) Alice no mosteiro das maravilhas de Tibães... - Espetáculo de marionetas.

Alice, uma personagem bem conhecida de todos nós, espreita por um monóculo e entra num lugar mágico: a cerca do Mosteiro! A aventura começa e no final da peça, todos são convidados a passear pela cerca à procura dos amigos da Alice.

Público-alvo: 4 aos 10 anos; Data e horário: março a junho, quartas e sextasfeiras, às $10 \mathrm{~h} 00$ ou 14h30; Tempo de visita: 2 horas; N.o máximo de participantes: 50 .

e) Exploração dos espaços monásticos - Atividade de descoberta da igreja e coro alto.

Com a ajuda de uma ficha/guia, os participantes desvendam alguns enigmas e partem à descoberta de pormenores existentes na igreja e no coro alto.

Público-alvo: 6 a 10 anos; Horário: às 10 h00 ou 14h30, de terça a sexta-feira; Tempo de visita: 2 horas; N. máximo de participantes: 1 turma.

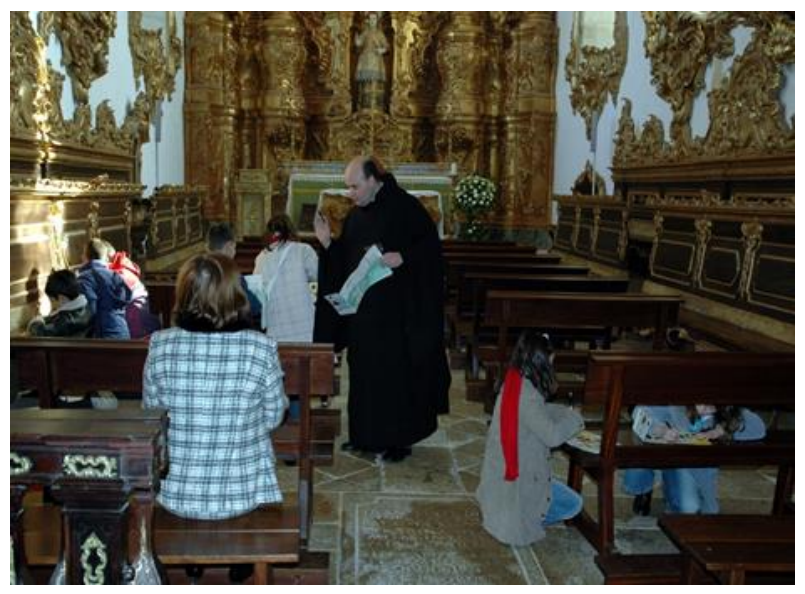

Figura 13 - Exploração de espaços monásticos: igreja. (2005, Arquivo do MSMTC, fotografia de Jorge Inácio) 
Loureiro, Joaquim Fernandes (2020). Percursos e desafios da mediação no Mosteiro de São Martinho de Tibães. In Alice Duarte (ed.), Seminários DEP/FLUP vol. 1. Porto: Universidade do Porto, Faculdade de Letras/DCTP, p. 62-97. https://doi.org/10.21747/9789898969682/seminariosv1a4

f) À descoberta do Mosteiro de Tibães - Visita guiada ao mosteiro e cerca.

Visita adaptada à idade, ao nível de escolaridade e aos objetivos previamente definidos pelos responsáveis do grupo. O Mosteiro é abordado como uma unidade e o participante é convidado a descobrir e a compreender o quotidiano dos monges beneditinos nos séculos XVII e XVIII. Na cerca é feita a sensibilização para a importância da educação e proteção ambiental.

Público-alvo: a partir dos 6 anos; Horário: às $10 \mathrm{~h} 00$ ou 14h30, de terça a sextafeira; Tempo de visita: 2 horas; N. 9 máximo de participantes: 50/60.

g) Os mistérios de Tibães - Uma viagem através dos símbolos.

Propõe-se aos participantes uma «viagem» pelo Mosteiro, para o conhecimento de alguns dos seus mais importantes elementos simbólicos.

Público-alvo: a partir dos 10 anos; Horário: às $10 \mathrm{~h} 00$ ou 14h30, de terça a sextafeira; Tempo de visita: 2 horas; N. máximo de participantes: 1 turma.

h) $\boldsymbol{A}$ horta tradicional - Atividade de experimentação e educação ambiental. $\mathrm{Na}$ cerca, num campo das antigas hortas, os participantes podem ver e experimentar técnicas de cultivo em modo de produção tradicional.

Público-alvo: a partir dos 3 anos; Horário: às $10 \mathrm{~h} 00$ ou 14h30, de terça a sextafeira; Tempo de visita: 1h30m; N. ㅇáximo de participantes: 1 turma.

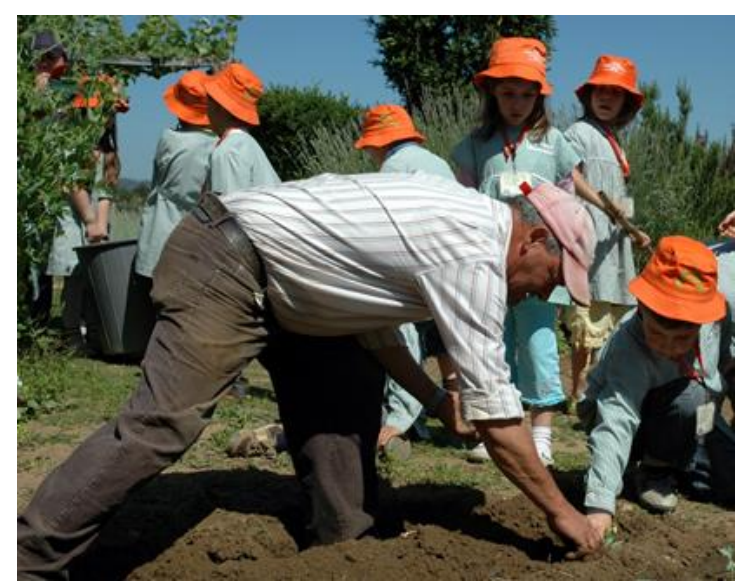

Figura 14 - A horta tradicional, plantação. (2009, Arquivo do MSMTC, fotografia de Jorge Inácio).

i) A biodiversidade na cerca - Visita aos jardins, campos agrícolas e mata.Esta atividade pretende explorar os diversos ecossistemas presentes na cerca, 
Loureiro, Joaquim Fernandes (2020). Percursos e desafios da mediação no Mosteiro de São Martinho de Tibães. In Alice Duarte (ed.), Seminários DEP/FLUP vol. 1. Porto: Universidade do Porto, Faculdade de Letras/DCTP, p. 62-97. https://doi.org/10.21747/9789898969682/seminariosv1a4

nomeadamente no que se refere à sua riqueza de fauna e flora. Os participantes são sensibilizados para a importância da preservação da biodiversidade.

Público-alvo: a partir dos 3 anos; Horário: às $10 \mathrm{~h} 00$ ou 14h30, de terça a sextafeira; Tempo de visita: 2 horas; N. máximo de participantes: 50.

j) Caminha, procura e observa... Os cogumelos - Visita específica sobre os fungos. Depois de uma pequena abordagem ao mundo da micologia parte-se para a cerca à procura de cogumelos, para se proceder à sua observação e identificação.

Público-alvo: 3 aos 10 anos; Data: Outono e Primavera; Horário: às 10 h00 ou 14h30, de terça a sexta-feira; Tempo de visita: 2 horas; N. máximo de participantes: 1 turma.

k) Contadores de histórias - Visita ao mosteiro, ouvindo e contando histórias.

Explorando o claustro do cemitério, a igreja, a sacristia e o coro alto, contam-se histórias sobre a vida de santos, o cerimonial dos monges e as profissões envolvidas na construção do Mosteiro. Pretende-se que os participantes sejam ativos e contem também as suas próprias estórias e experiências de vida.

Público-alvo: seniores; Horário: às $10 \mathrm{~h} 00$ ou $14 \mathrm{~h} 30$, de terça a sexta-feira; Tempo de visita: 1 h e $30 \mathrm{~m}$; N. máximo de participantes: 30 .

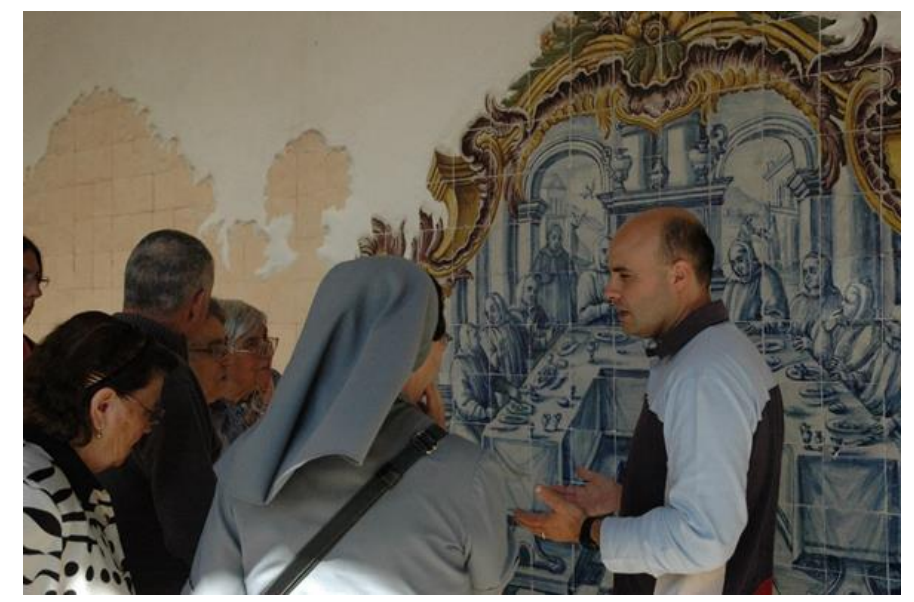

Figura 15 - Contadores de histórias, no claustro do cemitério. (2008, Arquivo do MSMTC, fotografia de Jorge Inácio)

I) A desfolhada - Atividade prática.

Retirar a maçaroca da cana, tirar o folhelho e a barba do milho, ver a cor do grão, deitar a espiga no cesto e levá-la ao espigueiro, sujar as mãos, sentir o cheiro da 
Loureiro, Joaquim Fernandes (2020). Percursos e desafios da mediação no Mosteiro de São Martinho de Tibães. In Alice Duarte (ed.), Seminários DEP/FLUP vol. 1. Porto: Universidade do Porto, Faculdade de Letras/DCTP, p. 62-97. https://doi.org/10.21747/9789898969682/seminariosv1a4

terra, são sensações únicas que se pretendem gravar na memória de quem participa numa desfolhada.

Público-alvo: a partir dos 3 anos; Data: setembro e/ou outubro; Horário: às 10 h00 ou 14h30, de terça a sexta-feira; Tempo de visita: $1 \mathrm{~h}$ e $30 \mathrm{~m}$; N. ㅇ máximo participantes: 50 .

m) $\boldsymbol{A}$ vindima - Atividade prática.

Passear pelas vinhas e pôr em prática os cinco sentidos, são os objetivos desta atividade. Ver as cores do outono, ouvir o som das folhas secas pisadas pelos nossos pés, cheirar os cachos de uvas, poder cortá-los e comer alguns dos seus saborosos bagos, são experiências que certamente nunca se esquecem.

Público-alvo: a partir dos 3 anos; Data: setembro e/ou outubro; Horário: às 10 h00 ou 14h30, de terça a sexta-feira; Tempo de visita: $1 \mathrm{~h}$ e $30 \mathrm{~m}$; N.o máximo participantes: 50 .

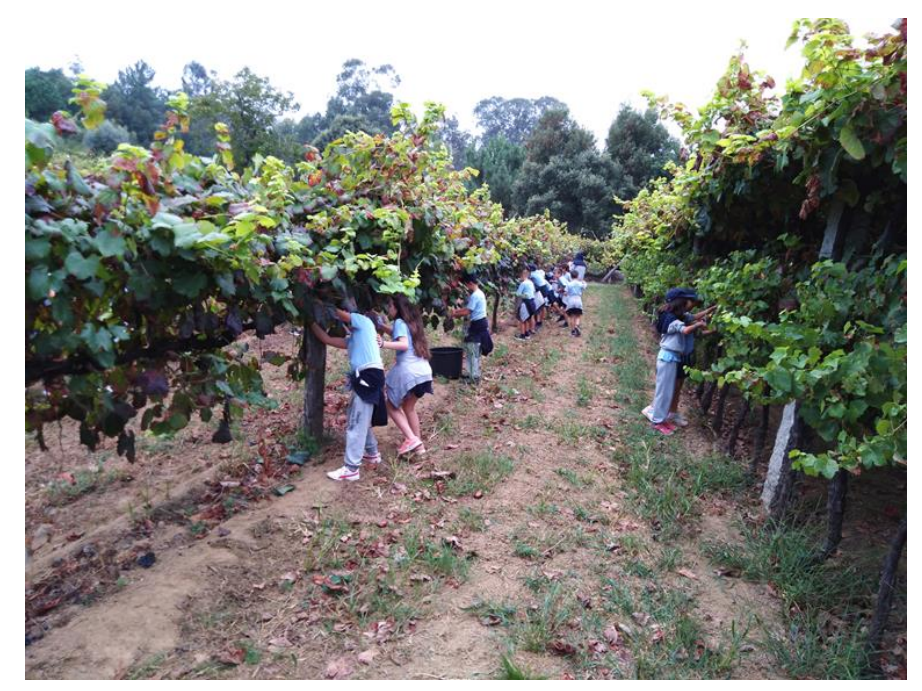

Figura 16 - Vindima, nos campos do Mosteiro de São Martinho de Tibães.

(2019, Arquivo do MSMTC, fotografia de Joaquim Loureiro)

n) Dias diferentes... Momentos de festa! - De acordo com o dia especial que se pretende festejar e com o tema que anualmente é proposto superiormente para alguns desses dias, são preparadas atividades adequadas ao grupo etário que visita o MSMT.

- Semana da Árvore e da Água (exploração das espécies de árvores, da biodiversidade e do sistema hidráulico existente na cerca); 
- Dia Internacional dos Monumentos e Sítios (programa específico a elaborar de acordo com a temática definida para cada ano);

- Dia Internacional dos Museus (programa específico a elaborar de acordo com a temática definida para cada ano);

- Semana da Criança (programa que inclui música, teatro, artes performativas, desporto e visitas guiadas);

- Jornadas Europeias do Património (programa específico a elaborar de acordo com a temática definida para cada ano);

- Semana de São Martinho (representação da peça de teatro de marionetas São Martinho, o Cavaleiro do Sol!);

- Pausas letivas da Páscoa e Natal e férias de verão (realização de oficinas de teatro, música, ciência, jogos. Visitas guiadas e exploração da cerca).

o) Outros projetos e parcerias Para além das atividades apresentadas, o Serviço de Educação está sempre aberto a sugestões e ao acompanhamento de diversos projetos. Organiza frequentemente várias ações com inúmeras instituições, destacando-se, entre outras, parcerias com: as Universidades; os Agrupamentos de Escolas; as Comunidades Intermunicipais; a Câmara Municipal de Braga; as Associações Desportivas, Culturais e Ambientais; o Grupo de Amigos do Mosteiro de Tibães; a Paróquia; a Junta de Freguesia; e o Grupo Folclórico de Mire de Tibães.

De facto, a localização privilegiada, a grandiosidade dos seus espaços e a existência de uma cerca conventual única, conferem ao MSMT a possibilidade de servir de base à realização de inúmeras atividades e projetos de carácter técnico, científico, educativo e cultural, assim como acolher grandes eventos, sejam eles desportivos, de moda, comerciais ou musicais. Gostaríamos particularmente de salientar a organização, realização, ou participação nos seguintes projetos e atividades:

- Projeto Museu, Escola e Comunidade. Mediação cultural com as escolas do antigo Couto de Tibães (em colaboração com o Instituto de Estudos da Criança da Universidade do Minho); 
- Projeto A Religiosidade. Levantamento das tradições religiosas existentes no espaço geográfico do antigo Couto de Tibães (em colaboração com o Agrupamento de Escolas Mosteiro e Cávado);

- Projeto CarryOn. Natural.mente.felizes. Serviços dos ecossistemas e o seu papel nos processos de apoio a vítimas de violência doméstica e violência no namoro (em colaboração com a Sociedade Portuguesa de Vida Selvagem, Universidade do Minho, Guarda Nacional Republicana, Comissão de Proteção de Crianças e Jovens e Associação Portuguesa de Apoio à Vitima);

- Projeto Aqua Cávado - O rio que nos une. Conservação e valorização do património e do território ribeirinho do rio Cávado (em colaboração com a Comunidade Intermunicipal do Cávado);

- Projeto Quem Tem Medo? Práticas simuladas do curso vocacional em contexto formal e não formal com um grupo de alunos com percursos de potencial insucesso, maioritariamente de etnia cigana (em colaboração com a E.B.2,3 de Nogueira, Escola Secundária Alberto Sampaio, Câmara Municipal de Braga e Transportes Urbanos de Braga);

- Projeto O Mundo Somos Nós. Ensino doméstico em espaços não convencionais (em colaboração com a Associação O Mundo Somos Nós);

- Projeto Integrar olhares para educar e formar. Atividades orientadas para jovens adultos com necessidades educativas especiais (em colaboração com a APPACDM de Braga);

- Projeto Caminhadas com História. Descobrir a história do MSMT e da Ordem Beneditina por terras minhotas (em colaboração com a Câmara Municipal de Amares e com a Câmara Municipal de Barcelos);

- Projeto Serões de Aldeia. Recriação dos serões minhotos inseridos nas memórias de Mire de Tibães. Desfolhada, malhada, botar as almas, histórias e lendas (em colaboração com o Grupo de Amigos de Mosteiro de Tibães); 
- Greenfest, o maior festival de sustentabilidade de Portugal, com programação enquadrada nos objetivos de desenvolvimento sustentável 2030;

- Augustacon, convenção internacional do jogo;

- Concertos e Masterclasses de música;

- Peças de teatro;

- Exposições (entre outras, destacamos os Encontros da Imagem de Braga, realizados no MSMT desde a sua 3a edição e as Artes na Escola, com a apresentação anual de trabalhos dos alunos das turmas de Artes de vários agrupamentos escolares do norte do país);

- Ciclos do milho, linho e vinho;

- Oficinas nas pausas letivas da Páscoa e Natal e nas férias de verão;

- Ciência Viva no verão - astronomia e biodiversidade;

- Eurobirdwatch;

- Encontros micológicos;

- Noite das criaturas das trevas;

- Conhecimento do património geológico e geomineiro da cerca, com visitas às minas de água e de volfrâmio;

- Conferências, palestras, debates, encontros;

- Discussão e reflexão sobre a estratégia cultural de Braga 2020-2030;

- Acampamentos na cerca (com o Corpo Nacional de Escutas, Associação de Escoteiros de Portugal e Guias de Portugal);

- Recriação de tradições religiosas e culturais;

- Provas desportivas - BTT (rota dos mosteiros); OriBTT; Orientação; Trails;

- Ioga, concertos meditativos com taças tibetanas, Chi Kung e retiros;

- Desfiles de moda;

- Cedência de espaços para filmagens de novelas, produções cinematográficas, documentários e séries televisivas;

- Encontros ao mais alto nível institucional (XXIII Cimeira Ibérica - 2008 e X Encontro Informal de Chefes de Estado do Grupo de Arraiolos - 2014). 
Loureiro, Joaquim Fernandes (2020). Percursos e desafios da mediação no Mosteiro de São Martinho de Tibães. In Alice Duarte (ed.), Seminários DEP/FLUP vol. 1. Porto: Universidade do Porto, Faculdade de Letras/DCTP, p. 62-97. https://doi.org/10.21747/9789898969682/seminariosv1a4

\section{A complexidade de uma pequena estrutura}

Como é possível desenvolver e colocar em prática todos os projetos e ações anteriormente apresentados? Que meios e estruturas de apoio existem? Quais são as dificuldades sentidas? Para responder a estas questões começamos por dar a conhecer, na figura 17, a atual estrutura orgânica do MSMT.

Integrada no Ministério da Cultura (MC), a DRCN é a entidade que tutela o MSMT. Estrutura-se em sete unidades orgânicas flexíveis e numa unidade orgânica nuclear, designada por Direção de Serviços dos Bens Culturais (DSBC), onde se insere o $\mathrm{MSMT}^{9}$. A equipa de trabalho do MSMT é composta por 13 trabalhadores permanentes, afetos ao mapa de pessoal, aos quais se juntam atualmente mais três - um ao abrigo de um Contrato Emprego-Inserção e dois pertencentes a empresas externas de prestação se serviços. A estrutura organizativa contempla a figura do Coordenador, pessoa responsável por orientar localmente a equipa de trabalho e conduzir a realização de todas as ações a desenvolver, de acordo com os objetivos gerais da DRCN e os objetivos específicos do MSMT, fazendo esse trabalho em articulação direta com o Diretor da DSBC.

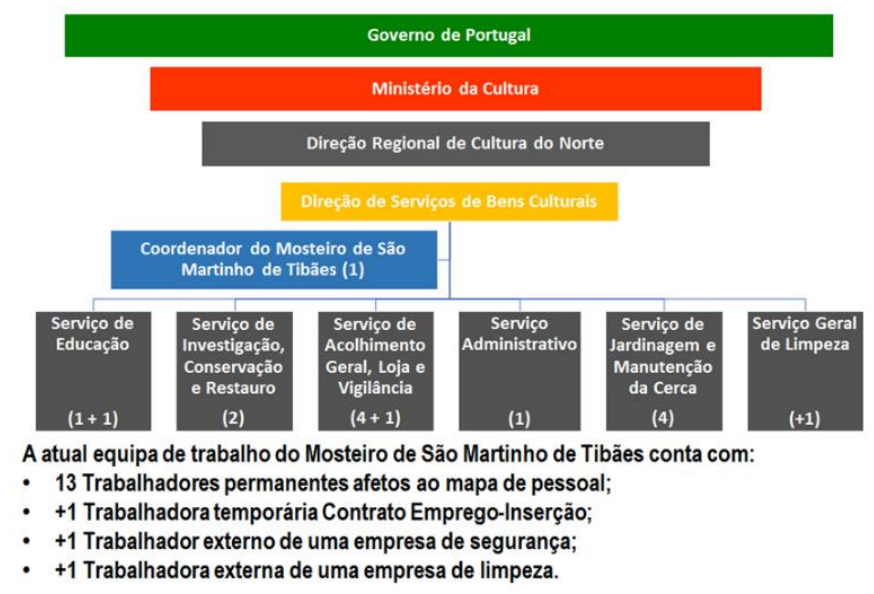

Figura 17 - Estrutura orgânica do Mosteiro de São Martinho de Tibães.

(2019, Arquivo do MSMTC, esquema desenhado por Joaquim Loureiro)

A restante equipa está afeta aos serviços apresentados na figura $17^{10}$, procurando, dentro das suas capacidades, conhecimentos e recursos disponíveis,

\footnotetext{
${ }^{9}$ A este respeito, consultar informação mais detalhada na seguinte página: http://culturanorte.gov.pt/pt/drcn/organizacao/, acedida em 04-11-2019.

${ }_{10}$ A designação apresentada dos serviços é meramente indicativa pois, como a equipa de trabalho é muito reduzida, há uma colaboração constante entre todos para realizar determinadas ações,
} 
Loureiro, Joaquim Fernandes (2020). Percursos e desafios da mediação no Mosteiro de São Martinho de Tibães. In Alice Duarte (ed.), Seminários DEP/FLUP vol. 1. Porto: Universidade do Porto, Faculdade de Letras/DCTP, p. 62-97. https://doi.org/10.21747/9789898969682/seminariosv1a4

trabalhar afincadamente no sentido de atingir os objetivos do MSMT, os quais passam por:

- fomentar o conhecimento do MSMT, da Ordem Beneditina e das suas relações históricas, artísticas, socioculturais e socioecónomicas;

- $\quad$ salvaguardar todo o conjunto monástico;

- recuperar, restaurar, reabilitar e conservar os diversos espaços do edifício e da cerca;

- contribuir para a manutenção e aprofundamento das relações entre as instituições que partilham a utilização espacial do mosteiro - Paróquia e Comunidade Religiosa;

- incentivar a produção artística tornando o MSMT um polo de inovação e empreendedorismo cultural;

- promover a educação cultural dos públicos, apoiada na realização de visitas e outras atividades de produção própria ou desenvolvidas em parceria;

- divulgar, através de diferentes meios, o MSMT e as suas atividades;

- estabelecer parcerias com instituições dos mais diversos setores de atividade procurando aumentar a oferta cultural e educativa, dinamizando os espaços.

Para que se alcancem esses objetivos é necessário conhecer muito bem a estrutura organizativa do MSMT e todos os elementos que compõem o conjunto monástico:

- estruturas construídas (igreja, edifícios conventuais, claustros e pátios, casa do volfrâmio, escadório, aquedutos, minas, fontes, chafarizes, lago, tanques, muros e caminhos);

- sistemas vivos (fauna, flora e fungos existentes na cerca);

- sistemas instalados e infraestruturas (águas, efluentes, eletricidade, iluminação, telefones, internet, gás, ar condicionado, aquecimento, som, imagem, vigilância, deteção de incêndio, intrusão e alarme);

independentemente do serviço específico a que pertencem e do conteúdo funcional que desempenham. 
- equipamentos necessários à acessibilidade (plataforma elevatória para cadeiras, cadeira de rodas, trepa escadas, elevador, rampas e áudio guias);

- equipamentos para limpeza, manutenção de espaços, conservação e restauro (aspiradores, máquinas de limpeza de pavimentos, motosserras, corta-sebes, sopradores, roçadoras, alfaias agrícolas, trator, grua móvel e andaimes);

- equipamentos informáticos.

Há a necessidade de ter operacionais todas as estruturas e elementos que compõem o MSMT, cumprindo a legislação aplicável, para ser possível receber, nas devidas condições de segurança e conforto, os visitantes da parte cultural e os restantes utilizadores do espaço, integrados nas atividades paroquiais e/ou da hospedaria. Também não nos podemos esquecer que, sendo o MSMT um monumento com mais de nove séculos de história é fundamental investigar e produzir conhecimento. Ao mesmo tempo, há um conjunto de informação que é concebida no presente, relacionada com a vida institucional, que é necessário tratar e arquivar para memória futura. Assim, para fazer tudo isto, os técnicos do MSMT - assistentes operacionais, assistentes técnicos e técnicos superiores - têm que ser profissionais de banda larga, com competências para:

- cumprir e fazer cumprir as orientações emanadas pelos superiores hierárquicos no que toca ao funcionamento interno da instituição;

- zelar pela salvaguarda e proteção do conjunto monástico;

- trabalhar em equipas pluridisciplinares que têm como fim a criação de ações que conduzam ao cumprimento dos objetivos da instituição;

- investigar para conhecer e compreender a realidade em que estão inseridos;

- definir estratégias para aproximar o MSMT do(s) público(s);

- projetar, planear e realizar atividades educativas, lúdicas e culturais adequadas aos diferentes tipos de público;

- proporcionar experiências significativas, capazes de operar transformações pessoais e sociais;

- acolher todos, sem discriminação, tornando o MSMT mais acessível;

- educar para o saber: ser; estar; ver; ouvir; sentir; proteger. 
Em suma, para atingir estes objetivos, todos têm que ser verdadeiros mediadores, utilizando as suas capacidades e competências para criar as condições internas e externas essenciais para a aproximação entre os públicos e o objeto que se pretende dar a conhecer: o MSMT.

\section{Os percursos e os desafios da mediação no MSMT}

\subsection{O que é a mediação?}

Comummente associada à resolução de conflitos, a mediação é hoje um processo ao qual recorremos estrategicamente para atuar nos mais diversos campos de ação, sejam eles de âmbito judicial, social, educativo ou cultural. Na mediação existe a intervenção de uma terceira pessoa - o mediador -, que procura, de forma imparcial, colocar em contacto os mediados, auxiliando-os a encontrar um caminho em que todos se revejam.

Diferente da negociação - em que ambas as partes têm que fazer cedências para chegar a um acordo -, a mediação atua no pressuposto de que todos os intervenientes no processo saem a ganhar. Torremorell (2008:34) considera a mediação como uma arte comunicativa que atua numa ótica transformativa, tornando as pessoas mais humanas e responsáveis. O processo de mediação implica primordialmente uma transformação pessoal - do mediador e dos mediados - que deve culminar numa transformação social, promovendo o crescimento moral, a revalorização, o reconhecimento, a auto e a coeducação, a transferibilidade de aprendizagens, a corresponsabilização, a cooperação, a participação e a cidadania ativa. Neste sentido, a mediação assume uma propriedade catalisadora e transformadora, das pessoas e do meio em que elas se inserem. A mediação enquanto processo e, posteriormente, como regulação social, vaise construindo no tempo, sendo geradora de aprendizagens que capacitam os intervenientes para liderarem responsavelmente com a sua existência. Não é um processo fácil, muito pelo contrário. Nele temos que ter sempre em conta as representações, a singularidade e a subjetividade dos indivíduos envolvidos. A mediação é também vista como uma ação facilitadora da desconstrução da disputa. Não mantém alianças a favor ou contra uma das partes, mas trabalha a favor da construção do Nós. É um processo de escuta ativa que usa o diálogo como intercâmbio de ideias, como 
Loureiro, Joaquim Fernandes (2020). Percursos e desafios da mediação no Mosteiro de São Martinho de Tibães. In Alice Duarte (ed.), Seminários DEP/FLUP vol. 1. Porto: Universidade do Porto, Faculdade de Letras/DCTP, p. 62-97. https://doi.org/10.21747/9789898969682/seminariosv1a4

expressão de sentidos e de significados e que cria momentos de convivência. Para Neves (2010:40) a aposta da mediação vai no sentido do «estabelecimento e desenvolvimento de uma comunidade emancipada que, congregando tanto mediadores como mediados, estabeleça novos patamares de participação cidadã e contribua para o reforço da justiça social».

No campo cultural entendemos que a mediação se assume como uma importante estratégia de construção de dispositivos que facilitam a aproximação entre o bem cultural que se pretende dar a conhecer e os públicos. Através de um processo de comunicação dialógico, pretende criar pontes que vão aproximar as pessoas ao património, consciencializando-as para a sua proteção, valorização e fruição, despertando assim o sentido de pertença e de identidade, capaz de promover novas práticas sociais. Para Buffet (1999:16), a mediação cultural diz respeito “... ao ajuste dos vocabulários, dos discursos e das palavras, dos sistemas de valores, e, através deles, à construção de um sentido partilhado".

\subsection{A mediação no MSMT}

Sendo em Portugal um conceito ainda em assimilação no contexto e discursos de âmbito cultural, a mediação acaba por ser um processo ao qual, todos os profissionais do setor já recorreram, mesmo quase sem dar conta. No MSMT, o termo aparece de forma mais explícita na sua história recente. Contudo, implicitamente, o processo foi sendo utilizado no MSMT ao longo dos tempos, tal como resumimos no esquema que se segue (Loureiro, 2013).

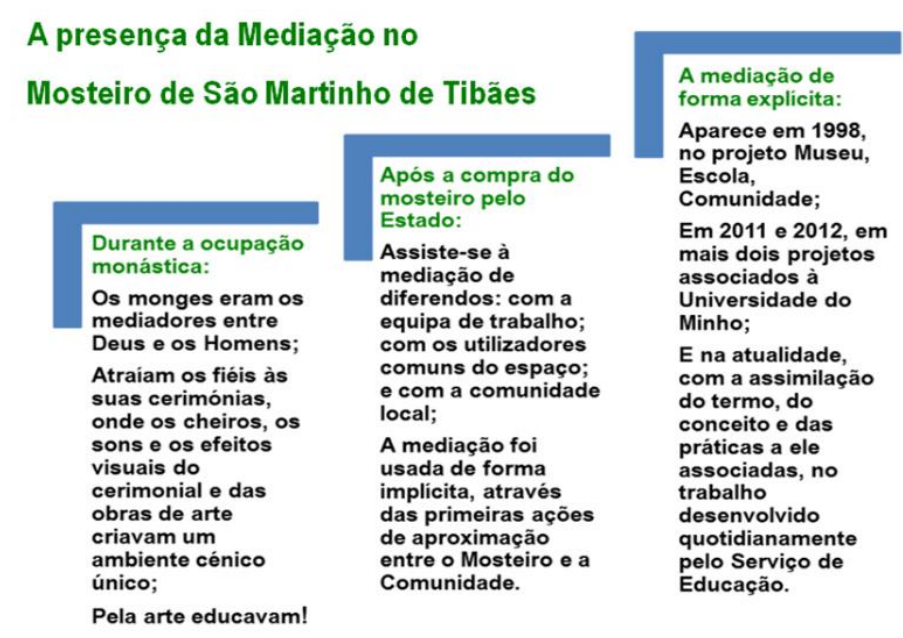

Figura 18 - A mediação ao longo dos tempos, no MSMT.

(2019, Arquivo do MSMTC, esquema desenhado por Joaquim Loureiro) 
Com efeito, os profissionais do MSMT sabem hoje que a mediação é um processo ao qual inevitavelmente têm que recorrer para desenvolverem a sua ação, com qualidade, dentro de um espaço tão específico. Essa consciencialização resulta da familiaridade crescente que o termo vai assumindo internamente, em parte, fruto da informação e formação constantes que vão recebendo por parte do responsável pelo Serviço de Educação, ele próprio especializado em Mediação Educacional. No entanto, no desenvolvimento de soluções para bem acolher o público, na criação de atividades que ajudam a interpretar todo o conjunto monástico em geral (ou algumas das suas obras em particular), ou mesmo nas relações com todas as outras instituições que coabitam o monumento, todos os técnicos do MSMT procuram diariamente dialogar com os atores desta enorme plataforma de relações. O seu objetivo passa naturalmente por encurtar distâncias, aproximar discursos e potenciar o surgimento de novas oportunidades de crescimento para todos, não descurando o respeito pelo outro, pela legislação em vigor, pelo património e pela sua utilização e fruição consciente.

\subsection{Os desafios da mediação no MSMT}

É nossa opinião que a mediação no MSMT tem um caminho repleto de desafios. Deverá ser a estratégia a utilizar para continuar a promover o diálogo e a colaboração entre a equipa de trabalho. Continuará a ser importante para as relações com as instituições que coabitam no monumento, ajudando a transformar possíveis conflitos em oportunidades de cooperação. Não poderá também esquecer a cultura do diálogo aberto com todas as outras instituições de proximidade, trabalhando em parceria, criando novos projetos e atividades, adequando-os ao contexto, ao espaço e aos anseios e motivações dos públicos, tornando o MSMT acessível a todos. Consideramos também que terá que manter e potenciar a sua identidade institucional, não esquecendo, contudo, os objetivos que Ihe são determinados pela Tutela.

\subsection{Os desafios do mediador no MSMT}

Ser mediador no MSMT é um desafio complexo que o obriga a ter um conhecimento sólido do passado para que, no presente, possa preparar o futuro, sem nunca esquecer as origens e a identidade do espaço e da região em que o mesmo se 
insere. É estar no centro de uma vasta plataforma de relações, mas com bases sólidas de conhecimento, que lhe permitam atuar com confiança dentro da área específica de cada um dos intervenientes, sejam eles o público individual ou organizacional. É conseguir estabelecer pontes comunicacionais que possibilitem a troca de informação e potenciem o conhecimento e crescimento mútuo. Se assim for, o mediador conseguirá certamente:

- manter e reforçar o bom relacionamento com as instituições que coabitam no MSMT;

- ter capacidade e competência para acolher bem e saber lidar com o público, pois nunca se sabe quem será o próximo visitante;

- procurar a inovação constante, de modo a atrair e fidelizar o público - inovar significa antecipar-se, estar mais à frente do que os outros;

- ser flexível, polivalente e comprometido para com o serviço, pois grande parte da sua função passa por proporcionar ao público momentos educativos, lúdicos e de lazer em horários pós-laborais ou de descanso semanal - o lazer de uns implica o trabalho de outros;

- convocar saberes nas áreas da Biologia, História, Arquitetura, Matemática, Física, Geologia, Geografia, Ciências da Educação e Ciências Sociais, entre outras;

- ver o visitante não como um número, mas como uma pessoa que tem necessidades específicas e que tem de ser tratada o mais individualizadamente possível;

- justificar constantemente perante a Tutela, de forma consistente, a sua função, a importância do seu trabalho e a relevância da instituição que representa;

- manter um relacionamento cordial com todos os colegas de trabalho, evitando e prevenindo conflitos;

- utilizar uma comunicação clara, adequada aos diferentes grupos etários;

- ter consciência de que será uma espécie de modelo e centro de atenções para o público que vai participar nas suas atividades;

- atualizar-se para ser um profissional assertivo e um educador credível;

- ter boa organização e gestão do tempo. 


\subsection{As características do mediador}

No centro do paradigma sócio construtivista, um mediador deverá ser um observador ativo, com capacidade para fomentar uma relação interpessoal dinâmica/positiva, encorajadora e facilitadora do desenvolvimento da aprendizagem. Deve conhecer-se a si próprio e (re)conhecer a mediação como processo de interação complexo. Cabe ao mediador promover e potenciar as capacidades interpessoais dos mediados, fomentando o autoconhecimento e a autorreflexão, para que, desta forma, possam mudar e transformar os seus comportamentos.

O mediador deve ser um líder positivo, ativo, ter capacidade de análise, pensamento criativo e estabelecer pontes comunicacionais. A confiança, a compreensão, a cooperação, a interpretação, a empatia e a escuta ativa são também caraterísticas fundamentais a ter em conta. Deve facilitar a solução, ser motivador, potenciar os erros, ser otimista, flexível, adaptativo, reflexivo, inovador, polivalente e ter a capacidade de improvisar. Deve identificar e caracterizar o contexto em análise e os intervenientes, ter responsabilidade social, prestar atenção, ser neutro (não julgar, não impor sanções, não aconselhar, não dar soluções), manter a confidencialidade, cooperar, interrogar, criar oportunidades de aprendizagem e promover uma cultura pacífica.

A escuta ativa, competência essencial de um mediador, acarreta em si mesma todo um conjunto de competências como o observar, parafrasear, clarificar, sintetizar, reformular e fazer questões circulares, promovendo a imaginação. Em suma, o mediador deve desenvolver sistematicamente um conjunto de características, competências pessoais, sociais e de formação específica pois, segundo Torremorell (2008:72), “o processo de mediação implica reencontro, reconhecimento, reconstrução, revalorização" dos valores culturais e ambientais.

\section{Os resultados}

As obras realizadas no MSMT permitiram a abertura progressiva de novos espaços, a recuperação de algum espólio móvel, a ampliação dos percursos de visita e a consequente produção e realização de atividades diversas. A valorização do 
conhecimento prático de alguns dos trabalhadores rurais que auxiliaram os primeiros trabalhos de recuperação, associado ao conhecimento técnico e científico de profissionais de áreas tão diversas - como a Arquitetura, Geologia, Biologia, História, entre outras - permitiu a troca de experiências e a construção de um saber partilhado, fundamental para a salvaguarda, proteção e valorização patrimonial.

Por seu turno, a implementação do Serviço de Educação veio capitalizar o saber multidisciplinar, transformando-o num conjunto de ações que fazem parte do programa permanente de atividades dirigidas aos diferentes tipos de público, sendo consideradas verdadeiras estratégias de mediação. Dessa forma tem sido possível aumentar a procura do espaço por parte de visitantes individuais, mas também pelo público proveniente de diversas instituições educativas de âmbito formal e não formal. O surgimento de novas tecnologias de informação e comunicação e a divulgação espontânea, feita por todos aqueles que visitaram o MSMT e gostaram da experiência, são outros dos fatores a ter em conta no que toca ao aumento do número de visitantes registado ao longo das últimas três décadas, tal como se demonstra na figura 19.

Contudo, tal como referimos ao longo do presente capítulo, o conjunto monástico é coabitado por mais duas instituições - a Paróquia e a Comunidade Religiosa. Desta forma, ao número de visitantes obtidos na vertente cultural do MSMT, temos que somar o número de utilizadores das suas outras valências: a cultual; e a de acolhimento. A título de exemplo, no ano de 2018, o número total de utilizadores do conjunto monástico foi de 92.892 pessoas, tal como se demonstra na figura 20. Este número é também muito importante, pois reflete a utilização total do conjunto monástico nas suas mais diversas funções e fornece pistas para estudos mais aprofundados sobre os públicos e a capacidade de carga do monumento 
Loureiro, Joaquim Fernandes (2020). Percursos e desafios da mediação no Mosteiro de São Martinho de Tibães. In Alice Duarte (ed.), Seminários DEP/FLUP vol. 1. Porto: Universidade do Porto, Faculdade de Letras/DCTP, p. 62-97. https://doi.org/10.21747/9789898969682/seminariosv1a4

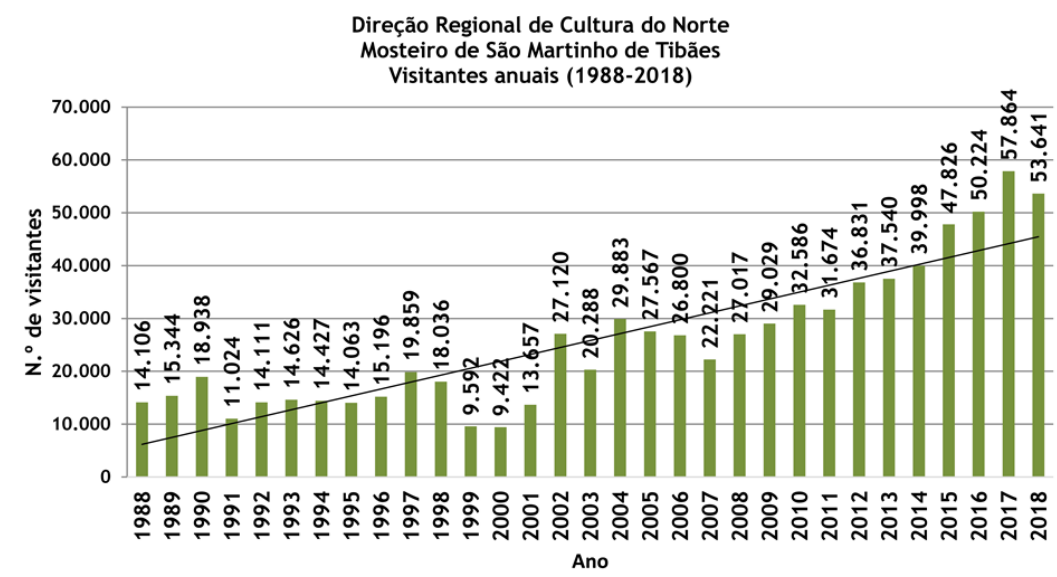

Figura 19 - Número anual de visitantes da vertente educativa e cultural do MSMT, entre 1988 e 2018. (2019, Arquivo do MSMT@, recolha e tratamento de dados realizada por Joaquim Loureiro)
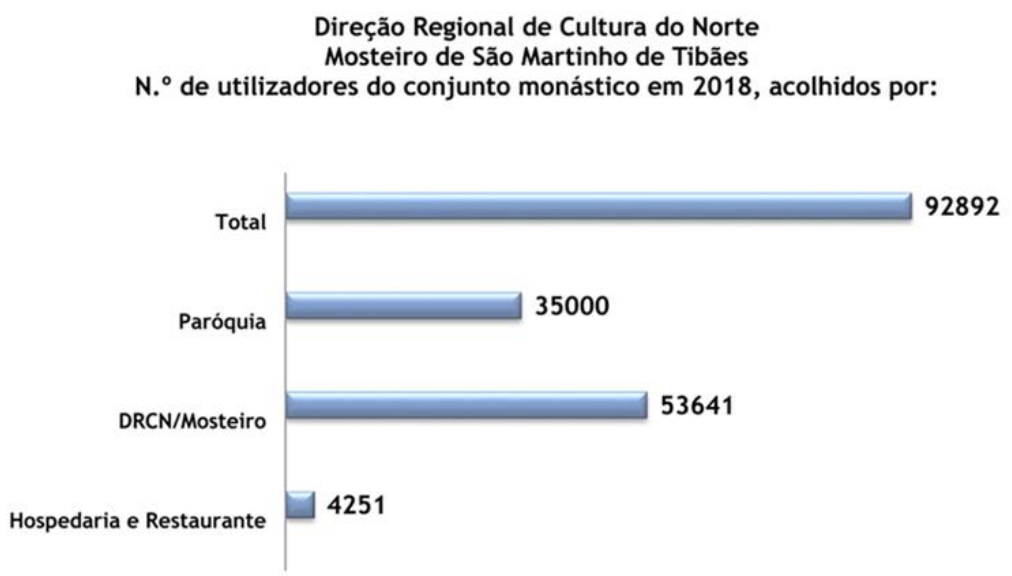

Figura 20 - Número de utilizadores do conjunto monástico em 2018.

(2019, Arquivo do MSMTC, recolha e tratamento de dados realizada por Joaquim Loureiro)

No entanto, há mais números para lá do público que o MSMT recebe. Referimonos em particular às receitas obtidas com a venda de bilhetes, com a cedência de espaços e aos custos associados à manutenção de toda esta pequena e complexa estrutura. $O$ saldo entre receitas e despesas é ainda negativo, mas o trabalho continua no sentido de tentar inverter a situação e tornar o MSMT mais autossustentável.

\section{Considerações finais}

O presente capítulo deu-nos a conhecer um pouco da história do MSMT, centrando o foco na sua vida institucional mais recente. A investigação produzida levanos a afirmar que o trabalho que tem vindo a ser desenvolvido no MSMT mostra a 
Loureiro, Joaquim Fernandes (2020). Percursos e desafios da mediação no Mosteiro de São Martinho de Tibães. In Alice Duarte (ed.), Seminários DEP/FLUP vol. 1. Porto: Universidade do Porto, Faculdade de Letras/DCTP, p. 62-97. https://doi.org/10.21747/9789898969682/seminariosv1a4

importância do entrecruzamento de áreas disciplinares no campo do património cultural relacionadas com a investigação, proteção, salvaguarda, valorização, gestão, educação e comunicação. Essa interdisciplinaridade coloca todos os técnicos do MSMT em contacto com outros profissionais pertencentes às instituições que também desenvolvem a sua ação no conjunto monástico, criando momentos de partilha e de crescimento pessoal e profissional que se traduzem no aumento da qualidade e quantidade das ações educativas e culturais desenvolvidas ou ainda a desenvolver. Estas parcerias tornam também o MSMT numa verdadeira plataforma de mediação em que todos os seus trabalhadores, independentemente da profissão e do cargo que ocupam, se assumem como verdadeiros mediadores, quer do ponto de vista interno (nas relações estabelecidas com todos os que coabitam o espaço físico do conjunto monástico), quer do ponto de vista externo, procurando constantemente estratégias que consigam aproximar o público visitante do bem cultural que se pretende dar a conhecer. Procurámos clarificar o conceito de mediação e aferir de que modo o mesmo tem vindo a ser assimilado e colocado em prática no campo cultural, quais os principais atores do processo e que desafios se Ihes colocam.

Os resultados apresentados revelam que ao fim de três décadas de uma nova vida, o MSMT é hoje um local cujo número de visitantes tem aumentado de forma consistente. Tornou-se uma instituição de referência no panorama educativo e cultural do norte do país e numa das mais importantes a nível nacional, quando falamos de conservação, restauro e reabilitação. Contudo, estamos cientes de que facilmente tudo se pode inverter e todo o trabalho desenvolvido ao longo das últimas décadas pode perder-se. Basta que, de repente, uma ameaça natural ganhe força (por exemplo um incêndio ou uma inundação) ou o foco principal de atuação deixe de estar centrado na educação, no património e nas pessoas e passe a ser direcionado unicamente para a vertente económica e financeira.

É função de toda a equipa do MSMT continuar a desenvolver um trabalho sério, profissional, pormenorizado, perfeitamente sólido do ponto de vista técnico e científico, baseado no diálogo permanente, focalizado na pessoa e não nos números, atento às ameaças internas e externas e às múltiplas sensibilidades que estão em presença no conjunto monástico. Assim será possível continuar a fazer do MSMT um espaço aberto a todos, um local de encontro de ideias, de partilha de conhecimento, onde a 
Loureiro, Joaquim Fernandes (2020). Percursos e desafios da mediação no Mosteiro de São Martinho de Tibães. In Alice Duarte (ed.), Seminários DEP/FLUP vol. 1. Porto: Universidade do Porto, Faculdade de Letras/DCTP, p. 62-97. https://doi.org/10.21747/9789898969682/seminariosv1a4

convivência entre o rural e o erudito se fundem em experiências educativas únicas, geradoras de mudança pessoal, educativa, cultural e social.

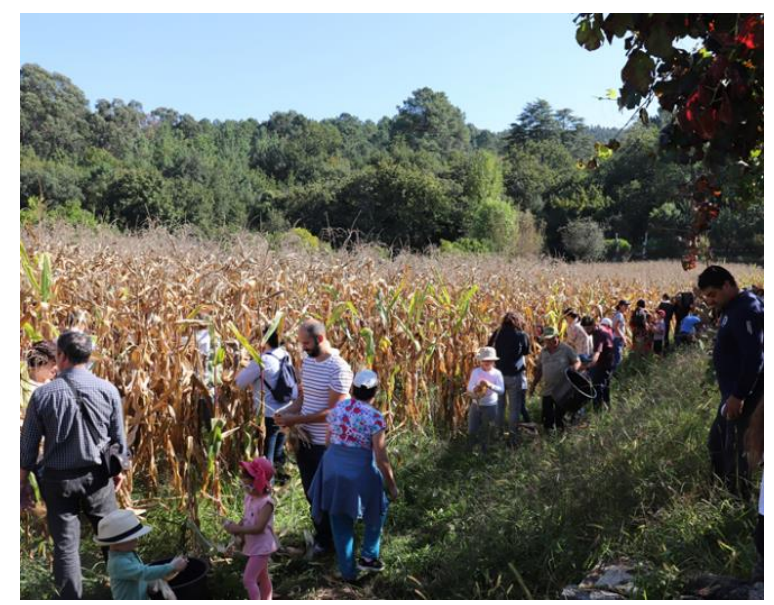

Figura 21 - Desfolhada nos campos do Mosteiro de São Martinho de Tibães. (2019, Arquivo do MSMTC, fotografia de Joaquim Loureiro)

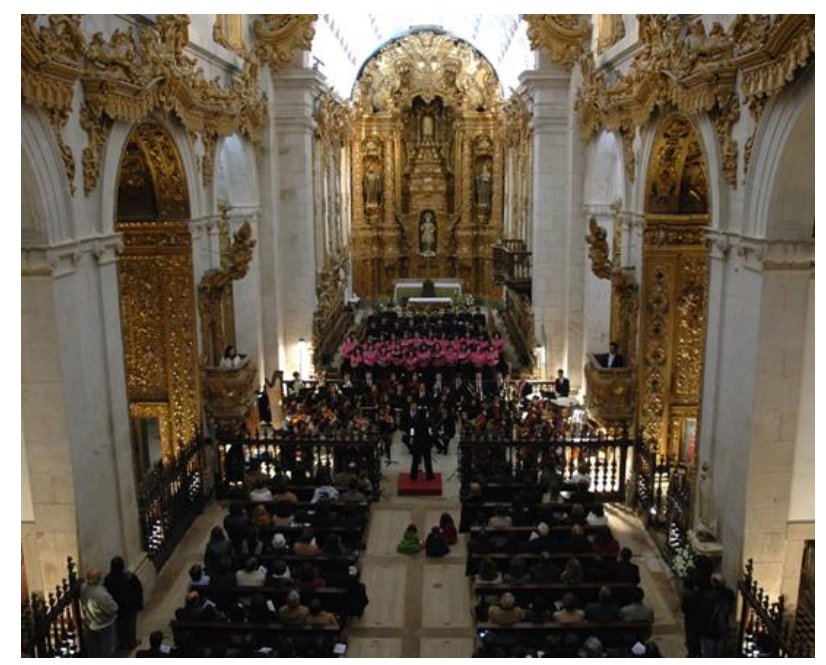

Figura 22 - Concerto na igreja do Mosteiro de São Martinho de Tibães. (2008, Arquivo do MSMTC, fotografia de Jorge Inácio)

\section{Referências bibliográficas}

Buffet, F. (1999). O Museu e a escola: parceiros de projetos educativos para uma problemática da co-educação cultural. In P. J. Fontes (Org.), O Museu, a Escola e a Comunidade (caderno 2). Braga: Centro de Estudos da Criança / Instituto de Estudos da Criança / Universidade do Minho, p. 7-26. 
Costa, S. (2010). O Mosteiro de Tibães: alas de dormitórios e celas. Lisboa: Âncora Editora.

Dias, G. J. A. C. (2010). Tibães: o encanto da cerca, o silêncio dos monges e os últimos abades gerais dos beneditinos. Porto: Mosteiro de São Martinho de Tibães e Mosteiro de São Bento da Vitória.

Dias, G. J. A. C. (2012). Quando os Monges eram uma Civilização. Beneditinos: espírito, alma e corpo. Porto: Edições Afrontamento.

Fontes, L. (2005). São Martinho de Tibães, um sítio onde se fez um mosteiro. Lisboa: IPPAR, Departamento de Estudos.

Loureiro, J. F. (2013). O papel da Mediação na construção da história contemporânea do Mosteiro de S. Martinho de Tibães (1987-2012). Relatório de Estágio não editado, Mestrado em Educação, Área de Especialização em Mediação Educacional e Supervisão na Formação. Universidade do Minho, Instituto de Educação, Braga.

Marques, José (1981). O estado dos mosteiros beneditinos da Arquidiocese de Braga no século XV. Braga: Câmara Municipal de Braga.

Mata, A. M. R. \& Costa, M. J. S. L. D. (1988). Mosteiro de Tibães. Braga: Barbosa \& Xavier.

Mata, A. M. R. \& Costa, M. J. D. (Orgs.) (1998). A Cerca do Mosteiro de Tibães. Lisboa: IPPAR.

Mata, A. M. R. \& Oliveira, E. P. (Orgs.) (2017). Conhecer o Mosteiro de Tibães. [s.I.]: Grupo de Amigos do Mosteiro de Tibães.

Mata, A. M. R. (2011). Vidas na vida de um mosteiro. Revista da Santa Casa da Misericórdia de Braga, n. 7, p. 87-168.

Neves, T. (2010). Modelos de mediação social. In J. A. Correia \& A. M. C. Silva (Orgs.), Mediação: (D)Os Contextos e (D)Os Atores. Porto: Edições Afrontamento, p. 3343.

Oliveira, P. J. C. (2005). A Congregação Beneditina Portuguesa no Percurso para a Extinção (1800-1834). Viseu: Palimage Editores.

Peixoto, J. C. G. (2014). Tibães, marcos e domínios. [s.I.]: [s.n.].

Peixoto, J. C. G. (2017). Demarcação territorial do Senhorio (couto) do Mosteiro de Tibães. In A. M. R. Mata \& E. P. Oliveira (Orgs.), Conhecer o Mosteiro de Tibães. [s.l.]: Grupo de Amigos do Mosteiro de Tibães, p. 169-195.

Pereira, Paulo (Orgs.) (1997). Intervenções no Património: 1995-2000. Nova Política. Lisboa: IPPAR.

Ramos, A. (2017). Couto de Tibães - Funcionamento do poder judicial e municipal. In A. M. R. Mata \& E. P. Oliveira (Orgs.), Conhecer o Mosteiro de Tibães. [s.l.]: Grupo de Amigos do Mosteiro de Tibães, p. 197-214.

Santos, A. F. (1987). Mosteiro de Tibães. Trinta anos para perder o rasto de uma memória de séculos (1834-1864). Braga: [s.n.].

São Tomás, F. L. (1974). Beneditina Lusitana (2 Vol., edição fac-similada). Lisboa: Imprensa Nacional Casa da Moeda. 
Loureiro, Joaquim Fernandes (2020). Percursos e desafios da mediação no Mosteiro de São Martinho de Tibães. In Alice Duarte (ed.), Seminários DEP/FLUP vol. 1. Porto: Universidade do Porto, Faculdade de Letras/DCTP, p. 62-97. https://doi.org/10.21747/9789898969682/seminariosv1a4

Torremorell, M. C. B. (2008). Cultura de Mediação e Mudança Social. Porto: Porto Editora.

\section{Legislação}

Diário do Governo n. 136/1910, de 23 de junho.

Decreto n.o 33587, de 27 de março de 1944.

Diário da República, II SÉRIE, n.o 242, de 18 de outubro de 1949.

Diário da República, I SÉRIE, N.o 225, Decreto-Lei n.o 307/90, de 28 de setembro.

Diário da República, Portaria n. 736/94 de 13 de agosto.

\section{Consulta na internet}

http://www.jf-miretibaes.pt/index.php/freguesia/mire-de-tibaes/um-pouco-sobre-afreguesia, acedida em 02-11-2019.

http://culturanorte.gov.pt/pt/drcn/organizacao/, acedida em 04-11-2019.

FILE:///D:/TRANFER\%C3\%AANCIAS/ATA N 16-

2016 DE 12 FEVEREIRO DE 2016 XI MANDATO .PDF, acedida em 06-11-2019. 